\title{
講 演 要旨
}

\section{1. 長野県南佐久郡内に於ける国保の実体調査}

長野 佐久病院 飯島 聖人・藤谷 美䓂 排出 泰助

現在, 病院経営の中で当面一番大きな問題の一つは何 んと云つても，年々増加する未収金にあると思う。この 未収金の内で最も回収状沅の悪いのは国民健康保険で, これが吾々病院経営に大きな影響をもたらすものとして との調査を行つた次第である。

1. 調查地区について

南侄久郡内の6国保組合に就いて調査しました。

\section{2. 調查方法については}

国保組合の資料穵もとに集録しました。

（表1）これは南传久郡內の国保組合の利用状況で受診 患者数並びに医療費が急激に年々上䒜の一途をたどつて 居る。

（表2）念激に膨脹した国保組合の収支の状況を見ると 医療費の年間芰払額は何れも一部負担, 保険料の収入額 を上迴り，表に示寸如く年々浐大な赤字を出している。 これを 1 町村当りに平均して見ると，25年20万，26年19 万 $3 千, 27$ 年 35 万 6 千の赤字になり，之の赤字年及 增加して来て居る。

（表 3 ）医潦費の膨張に比例し一部傎担金, 保険䊅の徽 収額の急激な上昇が見られる。この上昇カーブに対して 未収金を昭和 26 年 $18 \% ， 27$ 年 $21 \%$ と云万ような, 上 り急激な上昇を示している。この亨坆仪額一部负担金 保険料等組合員からの徽収を引き上げて見ても，やはり それに比例して未収率が多くなるばかりである。

（表4）以上説明した通り，国保組合は膨大な赤字と末 収金を出して居り，そのため表の通り年々膨大な補助金 が赤字補助と運転资金のために町村上り支出されて居り この額は年々增加し，町村斯政の命取りと云れれている。 （表5）次に国保組合未仪金と病院未收金との関倸につ い見る。国保組合未収金站に未払金の上昇虫，大㑣病院 の未収金の上帠と平䘕して来て属る。

（表6）現在までに説明したよ弓な国保組合の第状を改 善し育成するとして，政府では，本、年度総額 $\div 2$ 隐の国 庫補助を行うと云つているが，喿して苦境にある国保組 合立直しが出来るので㐫万らか，日田町を例にして調べ て見ると，この補助金は炏の四つの算出基準があり，第 一は振興装行力式，第二は財政力調整方式，第三療養給 付方式，第四保険料調整艾付様式により算出され，此の 万式にもとずいて計算して見ると，臼田町の補助金額は
約 30 万以になり，それを表で見ると， 27 年の収支の赤 字が，30万9千円，未収金は80万円て，佾，此の組合は 経営難のために入院した場合の賄費は見ていないから， 此度の補助金に就いてて政府の言ら五割給付をするとすれ ば，27年の大院延日数.2,824日て，その組合負担の賄費 は, 24 万门になる。赤字と末収金と賄費の合計は, 135 刀円で, これだけの金がなければどらしても, 経営はやつ ていけないのであるが，それに対して町一般会計から.42 8,000円の補助金が支出されていて, 政府の補助金の30万 円ではど5にるならず,体然として町からの補助金は,従 来通り支出されなければ組合の経営はやつていけない状 態である。倘，政府の算出基準によれば経営の苦しい組 合程補助額は少くっらくな組合に多いといら矛盾がある。 （表7）次に補助金に就いて具体的に臼田町を例にして 見ると，表に示す如く 27 年底と 28 年㢃を比較すると, 保 険料にしても，町の補助金にてても，殆んぞその影響は 見られない。份次に示す如くこの町の保険税の率は非常 に高く，町の三大税金の一つになつている。

\section{結 諭}

国保組合経営の行きづまりは, 被保険者に此れ以上の 負担をかけられない状態で，少し位の補助金では，とて もやつていけない現状に追いこなれている。この国保の

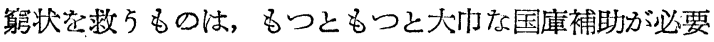
であり，資金的な伦機にある病院経営に対しても，医療 金融金庫の設置など国庫に依る低利資金の融資が必要で あると考えられる次第でる。

\section{2. 当病院の未収入金の問題}

長野 北信病院 町田 言雄・内堀 㑆 田川 紀夫・綿貫 英雄 米山ッキ子・山崎 より 阿部 信子

（1）当病院に於て経営上，現在最子悩夕は未収入金の 増加に依る資金の枯渴である。自己資本及び借入金 に対し未収入金は約 $64 \%$ \%市る。

（2）未収総額 700 万円に比して国保は $37,5 \%$ 一般は 10 .2\%で岁る。こて此の医療費を滞納して居る一般 患者と払込の悪い国保について，其の滞編の原因が 奈辺にあるかを調査して見た。

(3) 調査の方法

（1）一般患者 27年度中の未納者につきカードを配 初乙回答を求めた。

（2）国保 比較的良い国保之恶い国保の経営内容の 比較検討。 


\section{3. 病人が病院に来るまで}

長野 北信病院 井上 清幸・内堀たまじ 小島たけ子・花野きぬ 青木きくみ・岡本たけ子

私達は病気に羅られた農村の人達が比較的設備の整う た病院に受診に来るまでに，どの様な経過をへて来るか について，外来及び大院㭧者 298 名について調査して見 t。

直接来院せるものは $16.4 \%$,

26才〜40才まて㑑宣治療のみですま忧，また老人ほ

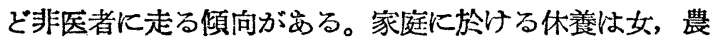
家の家庭に呿いては嫁は休養をとりにくい，又，山地ほ ぞ受診する事が困難で岁る。又，医療費の面ては健保， 生保のものが医者を訪れ易く，自費の者は自宅治療です ませてしま5。更迷信的な自宅的治潦，非医者的治療ほ ぞ有害無益が多い。

\section{4. 富山県湿田単作農村に於ける重要疾患群と} 其の対策について

富山 新湊病院作道分院 西田 重荇 北陸の湿田単作農村環境に於て, 現在いかなる疾病が 住民の保健対策上重要であるかを知るために，炤和26年 1 月より12月に亘る間, 富山県作道地域 (人口.4328) に 於て，医療の対象となた全㭧者につき，疾病調者を行つ た。この地域に於ける重要疾患の発生及び死亡による禍 の程度を山罯えてみると循環器疾患の脳出血が頂上 ( 死亡）をなし, 消化器疾㭧, 呼吸器矮患, 就中乳幼児の 下㥒，感目性疾患が主として中腹 (要療荃带) をなし， 寄生虫病，全身病，就中鈎虫及びビタミンB不足が裙野 (作業能率低下带) をなしている。この山の姿は, 湿田 単作農村環境から来る生活, 居佳, 労働条件の所庭であ つて, 白米中心の偏食 (ビタミン $\mathbf{B}$ 不足), 新鮮人肥の使 用 (寄生虫), 母親の過学 (乳㭃児の下浰, 感冒), 過学 等方”保健対策上の重要課題てむる。

2 の追加秋田秋田組合病院阿部展 七 1. 国保保険料の少くとも半額は国家て保障すべきもの であるが，財政的に珼困な都市，町村単位に運営する よりも，少くとも県単位に運営すべきものと考える。 出来れば国家で運営すべきものである。これは保険料 並洽付の不均衡の是正にも役立つ。

2、政府はただ単に国保設立を市町村に奖励するげけで なく，財政的の裹付けをして後，国保設立を漿励する よ5本会の決嬟として政府に進言すべきで市る。
2 の追加

私たちは，国民健康保険の全額国庫負担をスローガン に致して居る。南佐久郡は, 23 ケ町村の中，現在 9 ケ町 村のみしか国保を実施していなし，その中 3 ケ村は最近 再開したものでらり，再開しない町村は再開を熱望して いるにも拘らず，経済的な問題等から現在まて再開出来 ないるのであり，従つて，特話しの通り国庫負担，また は出来ない場合には県て運営することを決綒せよとのお 説に同意する。

5. 大分県農村巡回診療统計報告

大分 農民療養所 神田 栄治・城田 健夫 北崎 豪敏

私共の施設は結橫 180 を対象としており，定期的巡回 診療は今回はじめて。昨年未から本年麦杊入前まて，実 日数80日; 約6ケ月間 1 市5町31ケ村2612人にわたつた。 医師 1 , 看護婦 $1 ， \times$ 線技師 1 , 事務 1 , 自動車運転手 1,1 回 3 日間。

受診率は $1.3 \%$, 学校生徒は, 保揵所の巡回で要注意 といわれた者のみ。男子15一-40才が少く，女子15一25才 55一70才が多く受診した。疾病73種, 蜪虫 424 例 (受診 者の $16.2 \%$ ）胃腸疾㭧 $13.8 \%$ ，高血压 $13.9 \%$ ，気管支 炎 $13.5 \%$, 神経痛 $8.9 \%$, 肺結㮠 216 例 $(8.2 \%)$, 健康 $7.0 \%$, 鉤虫3.4\%, 以下略。農村生库活動を阻害してい, ると思われる高血圧, 神経痛V B 久乏症, 気管支炎並に 蜔虫症に対して連続的指導を要す（特に防寒，食邻に対 して)。殊に結核は開放性の 23 例の多数が工場, 軍隊に ての感染によるもの。䛦察時初めて見出されたるの15例 この内50〜 70才のもの5例, この中に㦑用中に発病し た2 家族内感染 1 め。20才以下の若年者には開放性を みなかつた。

6. 秋田県由利郡の巡回診療成綪に就いて特に 「レ」写其所見と检便成緥とを中心にして

秋田 由利組合病院 和泉昇次郎任吕 昭和28年 6 月から 8 月迄の間郡内30ケ町村中, 29ケ町 村の巡回診橑を実施した。受診者は総人口の $3.0 \%$, 4558名である。胸部の間接「レ」写真を㵊つたもの 3,592 名であつたが，湿性肋膜炎像を呈せる者10名，肺野に異

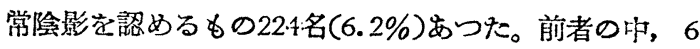
名は高年令層に属し，而子内 3 例は一次性肋膜炎々考之 られるものであつた。後者の中, 特に注意すべきは空洞 像を呈せる者 23 名中, 21 名が高年令層偊することて めつた。

検便数は 1,072 名厄蜔虫卵，陽性 $5.8 \%$ ，鈞虫卵陽

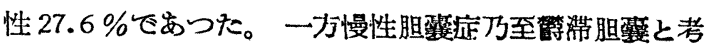
えられる広義の胆垔症が腹痛患者 395 名（一般内科受診 
者の $11.0 \%$ ○百分率に於て $22.7 \%$ 占め, 鈎虫卵が より大きな役割を演ずる様に思われた。但し之が時期的 地域的要因に関しては更に研究を要するところである。

\section{7. 最作業調查（第 1 報）}

秋田 平底病院 立身 政一・伊藤 剛・ 高橋常治郎

農村保健上，その生活環境気候風土の関係するととは 論をまたない所てあるが，特に農作業による過労が重大 なる影響を及はすすどろちとい5ことは，誰しも考える所 であり、しかも，この影響が積雪寒冷単作地带に於て, 殊に著明てあろちことは充分らなづけることてある。

かかる見地より，我々は東北の積雪寒冷地であり，単 作地带の代表とも言らべき秋田県平鹿郡吉田村桑の木部 落に於て, 各種農作業の調査及びそれに伴 5提取栄責, 休養り状沿を調查して居る。

今回は水田耕起より水田除草に到るまでの各種農作業 に就て, 各作業の能率と, 各作業の一定時間内に於ける 呼気をドーグラス震に探取し，之を学研式ガス分析器に より分析した結果を報告する。

\section{8. 繁期における「こうて」(手指津炎及び腱 㩆炎)について}

長野 佐久病院 若月 俊一・越川宏一・
山下 隆三

私たちの地方では，農繁期に，田植えや稆刈りの市と で, 過䇰のために, 手首のはれる病気のことを, 「こ5 手」と云つている。そして異性の人に，黒い糸てしばつ てもら5と治るとい5, 迷信的な風習が市る。

私たらは，まず之が，どのくらいの程度に農民を苦し めているか, 之を，4 ケ村の5CO 人の農民について，実 体調査をやつてみた。

その結果, 働、農民の約 $11 \%$ \%, 之にかかり, 又や られる䈱所は, 手の甲 (背側) の佰筋の睷, 又は腱鞘の 部分が，一番多いこと，又その発生時機は，夏の農繁期 (麦刚, 田植, 除草) の時が, 最も多いことなどが, は つきりした。

次に, 之を臨休的方面から追求すると，本院を訪れ た「こら手」患者の大部分が，手指の腱炎又は腱䩗炎て あり，又，中年以上の女性が多いことが注目された。蜸 及慢性化乙, 又 Akute Exazerbatiou を起す的の多 い。いわゆるTeudovoginitis stenosans の典型的なも のもある。その部位は, やはり手背部が多いのでるが その中で特に, Styloiditis rodii のかたちをとるるのが 多い。
さて, 更に一歩を進めて, 果して, 手の過激な運動か ら，このよ5な「こら厄」現象が起るか，どらか。之を 動物実験て行つてみた。

犬を長時間歩り廻らせること, 及ぴ電気モーターを用 いて，その足の屈伸運動を過激に起らせること。この三 つの方法を叜験した結果は，典型的な腱炎区び腱鞘炎が 起ることが病理組織学的に証明された。

(そのプレパラートを幻燈によつて説明する。)

犬る走らせた場合の Tendinitis, Tende voginitsは 前期の屈筋に特に著明にみられた。獣医学の方厄有名な 馬や牛の腱炎，腱䩗炎が，ちよ5ど，之にくらベられる と思う。「こち厄」はまさに，牛馬の如く働く人間の， 過労めシンボルと云つてもいいですろ。

1923年Sattler が Teudovagimitis akuta を, ブレ 一キ工や家具師の職業病として, 又1928年 Obolenskoja は, Tendouogimtis sesosa が, やはり工場学働者の病 気として，実験報告しているが，私たちは，之を農民の 病気としてとりあげた。もちろん根本的な治療法は，安 静厄方り根本的な予防法は農業労働の機械化であろ5。

\section{8 の罂問への答弁}

長野 佐久病院 若 月 俊一 田植の時には, 右手の伸㬳腱 (腱鞘) がゃらられます。 之は, 右手に苗を持つて, 土中にさしこむ運動のために 起ると考えられます。入, 稻刚り, 麦刈りの時には, 左 手の届等腱がやられます。之は，㺫り取るために，左手 で一ネ草たばをつかみとる運動りためてはないかと考え られをす。

御追加されたよ5な, 学働者口腱炎, 腱鞘炎について も同椂でありますが，(之については，Obolevskojaの くわしい研究がありますが, やはり,私たちの「こう手」 の場合ても，手指運動の未熟練「今などあまり使わなか つた」等腱を，念に過度に使うとい5ことが，この病気 の発生原因に大きな役割をするのではないか，と云らこ とを痛感して叔ります。

\section{9. 栃木県塩谷郡地方に於ける空生虫の}

䧐断並に治療状況予報

杤术㙁谷病院小山程 治 当院外来及び入院患者の寄生虫保有者の極めて多い事 に注目し,その保有及び治療の状洗について報告し, 作せ て当地区新制高校生徒の検便及び駆虫の状沿について述 ベたい。今回は予報として集畉法の優劣各種駆蛙刻並に

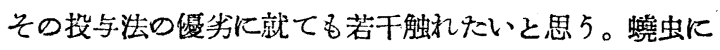
就ての検索に就ても調查穵進めているが，今回は省略す るととにする。今後調査の籍图を可反的に広め, 㙁行郡 
地区の寄生虫病莗延の状況を御報告する予定である。

9 の追加杤木 塩谷病院 小山穰 治

1) 検便の結果, 陰性者 (一回検便て) 中にも娚蝓を 服用させると，排虫することがかなり㟧る(雄虫だけ の場合は勿論でるが）から生笴生率ゆ正確を期する 意味に於ても, 又学校等に於ける集団彫虫们場合は陰 性者にも一応服用させて見る必要がある。

2). 銁虫の駆虫で一回の服薬で50\%以上ゆ駆虫率を兄 ている様であるが，自分の経験では。最近は薬品の性 質のためか，又は寄生虫の薬剤に対する耐性が出来て るためか一回の䁫虫戍服用で除性になつたととはない

3）農村に於ての疾㭧中，胃腸性疾㭧が特沉多い，媧虫 実施後の之ら疾患の消長との関係如何, 又国保を䒠施 している町村で集団駆虫をした場合，医療費の消長と の関係如何。私の実施した下都賀郡豊田村では駆虫後 国保の医療費交出が数十万節減された。

9 に対する追加 杤木 下都賀病院 小 林 芝 一 Ankylostoma duodenale そ Necator americanusuus とは分布を異にし，又両者は毒性を異にし，血液学的に 子臨林学的にも甚しく所見を異にし，駆虫薬に対する抵 抗に於ても甚しい美暴が品るのて，两者を区別して調査 すれば更に興味めることと想われる。莜便の集卵検査に 於て沈澱法と浮游法とは夫及の特徵が离るが, 鈎虫卵以 外の検出には適当厄ないと想われる。又アンチフォルミ ン沈激法に於ては, 吸虫㥸は小莣が破れ検出に团難なこ とがある。

10. 北信州一山村の集団檢便に関する検討（第 2 報） 長野 北信病院 泉山富雄・信州大学医学部学 生 浑辺元治・立川稔・小松崎修・塚池俊次・ 原正守

昨年に引続き，本年 7 月中旬上り長野県下高井郡住郷 村村民約 2,300 名に対し，集卵法に上る集団検便を施行 した。各虫卵の陽性率は若干低下したが，昨年 $37 \%$ を示 乙た銁虫笴生者は, 駆虫後虫卵除転竝儿陽性度の減少を 明かに示し，一力，新な鈎虫笴生者の生じつつある状海 子看守される。我及は本年の鈎虫寄生者に調查表を配布 乙て各種自他覚症状を統計し，その中約 300 名について の他覚的所見を記載し，又，硫酸銅法による全血，血墏 比重及ぴヘマトクリット値等を調べて，山村に潜在する 多数の鈎虫寄生者一殊に医家を訪方に至的奴者をも大き く含めた一の健康状態を広く把据すべく努力中である。
向，貧血著明の者には激虫の他に飲剂の服用をすすめ， 又, 駆虫後の自覚症状の变化についても追究する予定。

\section{1. 鈎虫の第川I期仔虫と胃液族度に就て（鈎虫の}

\section{経口感染に就ての検討)}

長野 昭和病院 松島 隆・青木 隆 須田 克泰・小島 英一

鈎虫の感染期（第3 期）にある完熱被囊仔虫は人体胃 液中及び腸液中に浸清されても，2時間以内に於ては殆 んば作用を受けずに生存し連動を続ける, $10^{\circ} \mathrm{C}$ 前後迄常 水斗に於ては, 運動活発にして $45^{\circ} \mathrm{C} 7$ 分, $48^{\circ} \mathrm{C}$ 温水 中では 2 分間で速動殆んど停止し，硬值状態に大るが， $48^{\circ} \mathrm{C}, 10$ 分阔上り死亡乚始め, $50^{\circ} \mathrm{C}, 10$ 分で, 総て死 減する。 $53^{\circ} \mathrm{C}$ 以上の温水市で注 1 分以内に総て死減す る。寒冷に対しては， $0^{\circ} \mathrm{C}$ 水中 2 分間で硬㨁するが死

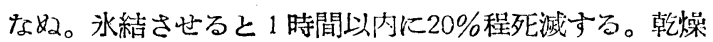
にに対しては, 湿度により幾分晶るが, 自然乾燥後 7 時 間迄は水を与元る事に依つて総て生きかえる。10時間後 て $21 \% ， 17$ 時間後では，75\%の死滤を見，29時間後 に於ては殆んど総てが死滅与る。是れに依り飲料水, 或 は生の野菜等上りの経口感染が今迄考えられていた上り も更に高率ではないかと思考する。

\section{参考文 献}

熊谷已三郎，十二指腸虫第 1 期第 2 期你虫の人工简液 に対する抵抗試験（慶応医学X11，1，昭和 3 年） 鈎虫症諺断の再検討 不原国 (最新医学, 7 卷 8 号, 炤和27)

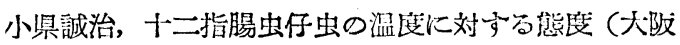
医学会雑誌XX11，II. 大正14年)

平井正純, 十二指腸虫被胞存虫の向性に就ての研究

(题応医学, 1X, 2. 昭和 4 年)

\section{1に対する追加}

富山 新湊病院作道分院 西田 重蕚

鈎虫の隹口感染が，実際に恃多いデろちとい5演者の 澺見に賛成である。

理由（1）富山県作道に於ける 2,415 名の調査で，無 烟非農家の鈎虫等生率恃, 173 名中, 25 名, $14.4 \%$ で, 村の平均符生率 $18.1 \%$ に近いるので方り，乙か子濃厚地 ほぞ隔くなつていた。（2）濃原溪浸部落に於ける家族別

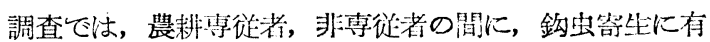
惫の差を認めなかつた。(3）幼時より，脳性小少麻瘁で 全然外步きの出来ない8才の女览にも鈎虫寄生を涩めた

\section{1. に対する追加}

私等は永年に亘り，鈎虫は固有宿主に感染する際には 
燕下された仔虫はそのまま䁑管内に於いて成虫になるも のてあることを実験的に証明して来た。ここに胃液に対 する抵抗力の点から，その感染の可能なことを証明され たととは興味あることである。

仔虫の乾燥に対する抵抗は乾燥の条件により都しく暴 なるものである。

\section{2. 虫垂桨時に於ける虫垂内検査成績につ就て} 杤木 下都賀病院 谪岩 清彥

昭和 27 年 8 月上り昭和 28 年 7 月迄の 1 年間の虫垂災 患者 239 例中，不在のため検査せざるもの91例，椧査物 採取確実ならざるもの5例, 虫垂切除不能 1 例, 検便せ ざるもの 38 例を除く 10.4 例の虫垂時に於ける 虫表内検 查成績について表示する事を, はぶきましたので, 扔判 り難いと思いますが，茂木教授の著「虫垂炎」と比較し て以下のべてみるに, 先ゔ

1）切除虫垂上り 19 例に寄生虫畉を梌出乙, 虫垂内上 り蜔虫 3 例, 鞭虫 1 例計 4 例の寄生虫を久た。寄生虫畉 の琽類は蜔虫畉最多にして17 例、ついで十二指腸虫卵 3 例, 鞭虫卵 1 例で岕るこの内蜔虫卵と鞭虫畉の 2 種 を保有したもの 1 例, 蜔虫卵と十二指腸虫畉の 2 種を保 有したもの 2 例㟧る。これ等の患者の梌便の成績空参考

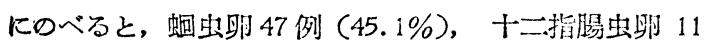
例 $(10.5 \%)$, 鞭虫畉 1 例, 東洋毛様虫甽 1 例であつて, 検便と虫垂内との寄生虫の検出率は，3:1て検便火よる るのが大であるが，虫垂内に一種丈は二種の寄生虫甽を 検し，あるい愓内に蜔虫を認めながら検便により，寄 生蝴を検出せざるすの 4 例ある。昭和 11 年安齊, 不川

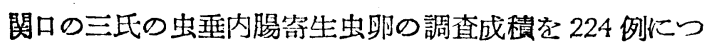
いて発表しているので, 比較して見るに, 蜔虫卵43\%と 発表しているりに刘し，89.4\% と約 2 倍の検出率となり 十二指脇虫卵 $6.4 \%$ と発挔しているのに対し，15.7\%と 2 倍以上の検出率となり, 文鞭虫については, $48.4 \%$ と 発表しているのに対し，わずかに1\%と大きな差がある のであります。これは份今後多くの症例によつて調查し たいと思5。次に

2）性別についてみるに，答生虫畉の検出率は男51例中 29例 (56.9\%)，女53例中，31例 (58,5\%) 飞多少女子 に多い程度で㐫りますが，左程間題にならない上5であ ります。多小本諭から離れますが，単に男女の䍜患率の みを見た場合，男に比して女が多くなつていることであ ります。蜔この事は既に1918年外国に於ては報告されて いる様でありますが，本邦にあつては明治 3.4 年，山形 氏は男女の比は $5 ; 1$ 之報告し，爾来漸次接近している 様でありますが，茂木教挼は昭和12年男女の此は18:1 で
あると報告し，虫垂炎が女子に多いと云万実証を認めな いといわれ且外国と相畋のある事と考察し，外国飞性食 物站に生活様式が男女の間に著しい差異がないが，本邦 に於ては相当に差晎があるからだろらと云われている事

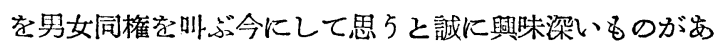
ると思いまして，少しくつけ加えた次第である。次に

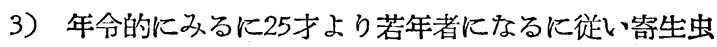
卵の検出率高く13才以下に於ては 1 名の虫垂切除不能な るのを除き他検出されている。又年令的に罪患率をみた 場合。1才より 30 才迄に罹患率の高い事は昭和10年茂木 教授の報告されたものと大体同じであるが，10才以下同 で，11 才より 20 才迄の罹患率が今迄の報告より高い事 を，合世て考光るとき，若年者の虫垂炎が成人に比して 寄生虫又は笴生虫卵の直接間接の誘因によるものが大て 岕と考えられるのではないと思 5。又，一方下都賀 地方の年少者の虫垂炎は, 解剖的伐人の様に, 細く長 く漏斗状をなしているものが少い為, 多いのではなから らかとも考元られ, 以上の事は一概には可論云えないと 思5。

4）次に冀塊特に算不についてみるに, 冀不楉いけの に多い様に思われる。これ虫垂が何等かの原因て，一 見炎症を来し，蜻の一部が狭窄状態となつを時それよ

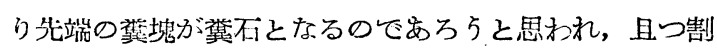
合大きなものが再発性の壊依性又は穿孔腹膜炎を来す様 でありますが，との詳細の報告は次回にしたいと思いま す。

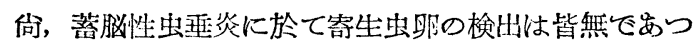
た事を追加して置く。

\section{2に対する追加}

腸管の解剖的関係から考え, 虫卵が特殊な变化ない場 合に，腸管外に出ることは考えられないので, 成虫が腸 管を穿通して腹腔内に透出したもので㟧ると解するのが 妥当と想われる。

\section{3. 蜔虫卵性腹膜炎の 1 例}

岐皁 西濃病院 森 直之

右側腹部の超手挙大腫癌を腸間膜腫瘍の疑にて開腹す るに, 上行結晹の内側に坐ぜる腫瘍にて, 網膜腹膜に撤 種を認めたるを以つで手術の意義少なしと考えたるも， 敢えて右半結腸切除術を行いたり，切除標本を切開する に蜔虫を一匹色埋せる腫瘍にて, 検鏡上, 該睡晹立に栗 粒大転移は主としてエオジン, 細胞よりなれる尖症的䐺 瘍にして，粟粓大播種のト心には蜔虫畉学認めたり。

13の追加 
腹膜腔内に成虫蜔虫を原因とせる化膿性腹膜炎 4 例を 経験し，乙かも腸の架孔部を発見しない。斯る例は，虫 体が腸壁を通過せる後, 遊激腹膜内にて成虫になるるの か，又は成虫が腸壁を穿孔せる後，腸壁は治湴せるもの かの問題がある。但し蜔虫卵が晹壁を通過するとの交献 はある。

\section{追加香川 哃川診潦所 池浦 義夫}

農村に於て寄生虫の間題は実に大切である。之が治療 は相当に医師に於て研究され, 又農民も駆虫の大切な事 を感ずる者が多くなつて来た。しかしこの预に就いて はをげ徹底しない感がある。「若菜病」は幼虫の人体内に 浸入した時に起る一つの病症である。この若菜病はCem moncoed,アレルギー性疾患の症状を呈するものでる この若菜病を発見してこれに侵されぬ様に農民に教える ことは, 寄生虫感染䂆方の一助となることと信ずる。

\section{4. 土佐に於ける風土病的㷊性疾患後の眼症状} 之免疫学的搒断 (第 2 報)

高知 香長病院 岡宗 重久・山本 敏雄

我々はささに土佐に於ける虹彩炎, 虹彩毛㥞体炎及び 硝子体溷濁の原因には，ワイル氏病の外に，これと類似 の疾患である「レプトスピラ」病が㐫るととを推論した。 爾来之等原病と思われるものの鑑別をする為に，思者血 清の凝集反応を行つた20 例について報告した(第 I 報)。 以後更に 20 例を追加し検索した結果, この地方に於て は秋季「レプトスピラ」病b 刑及びワイル氏病を主体と し，それに秋季「レプトスピラ」病 A型及びC型が混在 するととを証明することが出来た。

15. 南佐久地方に於ける眼突患に対する家庭療 法に就いて

長野 佐久病院 吉田 交子

農村には眼科医の治療を受けられぬ患者が多い。之れ を笑際に調査した所，迷信を含む新謂民間燎法が重要な 位置を占めている事が，判明した。之れを打開する方法 は農村の封建性を打破するは旸論，根本的には，医者が るつと多く農山村に大り込をねばならない。

16. 前眼部アレルギー焱に関する実験について

栃木 下都賀病院 清沢 兼人

馬血清に依る家乘の実験的アレルギー性結膜炎，及び 角膜炎の細隙燈顕微鏡的所見を述べ，アレルギー性角膜 炎の発生機序の考察並びに抗ヒスタミン削, ルチン其他 2，3薬物历抗アレルギー炎性に就いて述べる。

17. 南佐久地方に於けるトラコーマに就いて(第1報) 長野 佐久病院 小口 悌示 (1)全国的に見て長野県は,トラコーマの非常に少い県て
あるが，その中で南佐人郡は，所謂トラコーマ地方をな している。

(2)その原因は，種々あるだろらが，常水が関係あり。 (3)女性に於て罹患率が大であるが，これも常水に関係が める。

(4)トラコーマの多い地方には, 臚胞性結膜炎が多く, 之 れはトラーマの発生機転に関して，一原論者の意見を支 持するものと思われる。

(5)トラコーマの撲滅には, 農村に於ける社会的環境の改 善が，治療に先行すべきすのでる。

18. 晨村学童のトラコーマ䍜喣状況とその 対策について

杤木 佐野厚生病院 阿久津義夫

1. 栃木県下の㖘村学童のトラコーマ罪息率恃, 抽出 統計て 30 \%前後で㐫つて, 都市を﨎るるに従つて上昇 する。

2. $0.5 \%$ \%ラマイシン軟摬点眼㙩法を 3 ケ月間継繶 した結果, その過半数の治橑を得た。

3.トラコーマの集団検彭, 集団治療は, 学校に於て 最も好成績を挙げることが出来る。

4. 学校に於ける定期身体㭘查は, 専門医の検彭を必 要とするととを痛感した。

5. 学童のトラコーマ集団枱診とその対策虫, 地域社 会の理解を高めると同時に，公乑徫生の普反に役立つた

追加北海道 旭川厚生病院 藤井 敬三

北海道の農村ては, 調査の結果, 意外に少く, 2-3\%

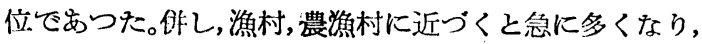
20 \%位になつて特る。之は潮風によるものかと思 5, 叉 北海道農村では, 殆ど室内ストーブを伐用して牱り室内

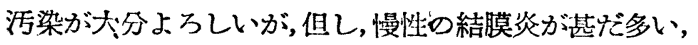
之は, 寒冷, 汗流等の物理的刺㦸によるものと思われる。

追加香川 鴨川弪療所 池浦 義夫

香川県の山村の用水不便の地の学童にトラコーマの多 いととにより生活状況を調査の結果, 毎朝洗顔せず登校 する学童の多いことが判明したのでこれを玫善したとこ ろ減少した, 又農村, 漁村の学童にトラコーマの多いの は蝴の多いことによると考える。農村, 漁村の子供の睡 眠状態を見るに，眼に蠅のとまることが多く，睡眠後に 家庭及び学校に於て清水で洗眼すること丈でも減少した 交化の進歩と,トラコーマ患者の减少とに関係がある ものと思考す。

\section{追加} 長野 佐久病院 小口 悌示

急性トラコーマが，急性膚胞性結膜炎の应状で始まる からそれれと鑑別はむづかしく，経過を1ク月間続け 
て観察せぬと，間噠い易い。

\section{9. 各稫消化器疾患の血釈定悬成績について}

吱帛 昭和病院 稻沢 光平・水谷 公治 炤和病院の外来及び入院想者について，葡蒛糖二重負

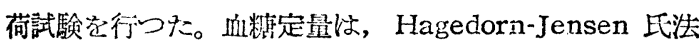

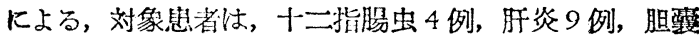

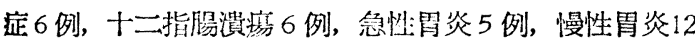
例，合計 42 例飞㐫る。男女别厄は。男 21 例，女 21

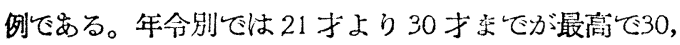
95\%である。「スタウプ」効果陽性改び陰性のものは， 十二指晹虫症では，2 例及び 2 例，肝炎では 4 例反び 5

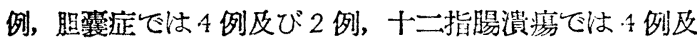
び2 例，急性胃炎では全部 5 例共陽性，慢性胃炎では 8 例及び4 例である。以上により黄瘨を伴5肝炎ては「久

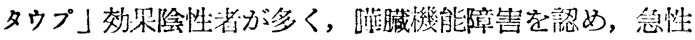
胃炎 5 例共陽性で，瞒機能正常なるを認めた。

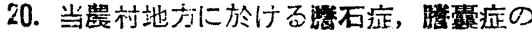 問題について}

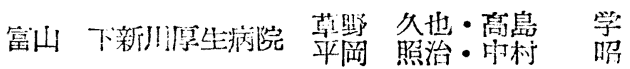

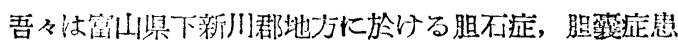
者の頻良を調查せるに，内科受診全思者に刘する比，内

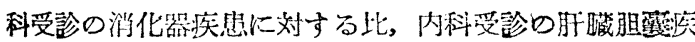

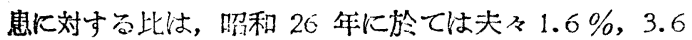
$\%, 66.4 \%$, 昭和 27 年に於ては去々 $1.7 \% ， 4.4 \%$, $44.8 \%$ ，昭和 28 年 (1月より 7 月安て) に於では，夫 ห1.6\%4.4\%, 55.6\%で方つた。

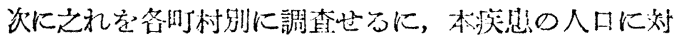
する比，各町村よりの受彭㭧者に対する本疾患の此，各

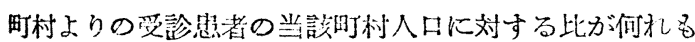
各々の平均率0.19\%，1.7\%，11.0\%より 多小町村孝 選出せるに，東有施，前沢，做野，青木，小摠戸，新屋，

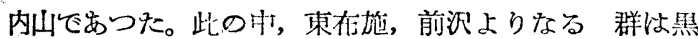
部川の流域に属さず，又川水飲用者㫐少ないが，飯野， 青木，小摺戸，新屋，内山よりなる群は照部川流域に用

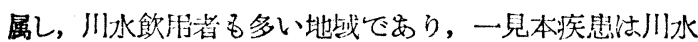
领との間に因果閔係㐫るやに見えたが，各症例について 领料水の別を調查し，これを当該町村仕民の领料水の別 とを比較众討せるに，関係なきことが推定された。

次に本疾患の頻度と職業（農業, 非農栄）との関係を 知らんとして，谷症例に於ける職業別と当該地域に於け

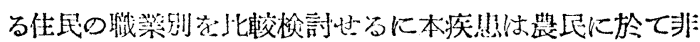
常に多いことが推楚された。

\section{1. 外科からみた当地方の䀶道浩患}

富山 下新川厚生病院 吉友 睦 過去約 1 年半の間に手術されを約 20 例の胆道疾患に ついて考察を加えてみを。

この守の過半数は些際に結不の㴓められた真性の䏣石

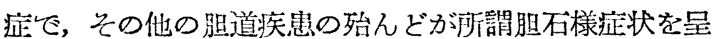
して胆不のみとめられないもので，われわれが特に注目 乙強調するところのもので㟧る。この疾患は，胆道疾患 全体に刘する比率からみてかなり多く，ことにその発生 原因, 特畋的症状, このものと当地方の地域的関連性等 について論じてみた。

当地うの㭧者の殆んどが農村人である点，一面農村の 胆道疾患と云うものに対する何かの参考になれば幸いて 另る。

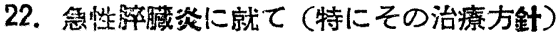

富山 埧川病院 平非 基弘・石政 栄造

5 例の念性脺䁍炎（时血堎死型 2. 壊死型 1。浮睡 型 2.）に遭遇乙，全例何れも 70２0 才間の女性に現 れて来ている，5例灾例 4 例迄は急性虫垂炎，骨盤腹膜 炎, 蜔虫症と䛦断治燎付，或怡潦後，吾々の外科に送 院されたもので， 3 例远は所謂非定型的な腹部所見を呈 吼るもにて，開腹術飞当り，先づ右副直腹筋切開，下 正中線切開，ヶール氏波状切開を行い，腹部臓器の榆索 の結果，本症であることが判明した。

本症に対する観血的治喑，殊に非定型的なものに対す る観血的治療は診断の磪立，脺臟病变の輕重を把握し， 棥後の治潦指針を与える点より観血的潦法に替同した。

\section{3. 疽道並に脺緘疾患の相関性に関する研究}

青森 西北病院 永沢正三郎・传藤 吉美

最近経験せる胆道並に，脺疾患 108 例を基として，闭 者の相関性汇就き，種々検討したが，

（1）胆道疾患 49 例中，28 例即方 $57 \%$ \%，特発作 期では $78 \%$ に胆汁内脺液酻素の出現をみた。

(2) 胆道疾患 93 例中 50 例, 即ち $53 \%$ に尿 デアスタ 一七゙値の上昇を久，面に $43 \%$ に手術時，脺炎の件発を 認めた。

（3）胆道疾县の手術に際し，手術侵謷の大なる胆翼剔 出例ては, 術後 4〜5 日尿デアスターゼ值は, かなり上 帠し，2 週位で正常健に復するに区し，手術侵裂の小な

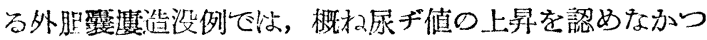
た。

(4) 胆通垁䍐にて術前尿デ値正常なりしるの43例中, 
術後 $88 \%$ に尿ヂ值の上昇を認めた。

(5) 明らかに胆汁の脺管内逆流により生ぜしと思われ

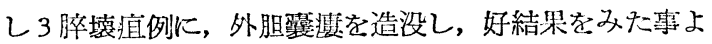

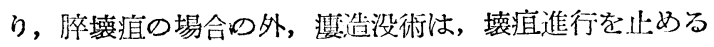
ため相当の治療目的を有するるのと考える。

\section{4. 当院外科に於ける胆囊疾患の集計的観察}

秋田 由利組合病院 寫田 佾彥・日野 博裕

当院に於て過去 15 ケ月に施行した胆聚疾患の手術例 36例について，集計的観察を試みた。性別よりすれば， 女性にやや多く，手術所見に基いて分類すると，胆道内 蜔虫迷入症 9 例, 胆石症 5 例, 急性胆鋯炎 6 例, 慣性胆 裂炎 18 例, 結石は数年来の疼痛を有する者多く, 迷大 症は発作開始後数日以内の者が大部分で安つた，大部分 は, 上腹部, 右季肋部痛飞しか子激痛を訴へ, 半数に雭 心煰吐艺みた，37。C 以上の発熱出る者約半数で, 念性

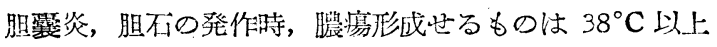
の発熱をみたものが多く，迷大症は，不定であつた，白 血球増加は，12 例に久られ，念性胆翼炎区び胆不で膿 瘍形成したものに著明に認めた，迷大症では，增多は見 られず，岀つても輕度であつた，右季肋部压痛は全例に

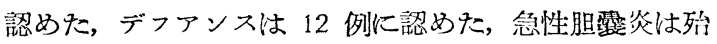
んど全例に，迷入症はとの $3 / 1$ にデフアンスをみ后 季助部に抵抗を触れたるの10 例で，はつきり胆焣に触 知したものは，4例で虫つた，入院時黄胆を認めた者 3 例, 既往に黄胆を伴与疼痛空有した者 4 例で, 胆石症, 慢性胆殧炎に多く，迷大症には見られなかつた。ウロビ リノーゲンは，4例に見られ，発病以来の経過の長い者 に多くみられた。

\section{追加香川県 鴨川䛦憭所 池浦 義夫}

急性脺臓壊冝の診断は内科的には, 最も困難を感ずる ものである。鑑別すべき疾患としては, 胃潰瘍, 胃癌, 胆石症, 胃, 十二指腸浿㾤, 虫垂炎等であるが, 疼痛の 激しいこと殊に橫卧，仰臥は团難で立位の售で疼痛を訴 える様である。発熱は病部に認めず，腸閉寒症状を呈す るととも多し, 便の性状に於て, 精液様の腸排泄物を認 める战鿁にあり，低つてまず浣渴により，精液様腸排泄 物を見たるとさは，脺蔵疾患と診断する一助となし得る ものと信ずる，余の例 1 例に於て，この精液栐腸排沘物 を見るにより櫵臓壊疽と診断し開腹術により確診した。

\section{5. 当地方に於ける赤冽発生の年次的}

$$
\text { 変要について }
$$

長野 北信病院 标市 徽郎・泉山 䈏雄

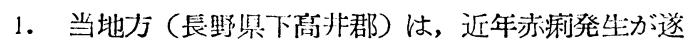
年激增して止る所をしらない。

\begin{tabular}{|c|c|c|c|c|c|c|}
\hline 年 & 23 & 24 & 25 & 26 & 27 & $\mid \begin{array}{l}28(8 \text { 月 } \\
31 \text { 日現 } \\
\text { 在 }\end{array}$ \\
\hline $\begin{array}{l}\text { 赤 痢 発 生 数 } \\
\text { 発生摔(対人口10万) }\end{array}$ & $\left|\begin{array}{r}10 \\
11.1\end{array}\right|$ & 147 & $\mid \begin{array}{r}25 \\
27.2\end{array}$ & $\begin{array}{r}289 \\
333.0\end{array}$ & $\begin{array}{r}375 \\
438.0\end{array}$ & $\begin{array}{r}512 \\
599.0\end{array}$ \\
\hline
\end{tabular}

2. 柇別にも, 26年以降は山間僻地, 如何なる土地に

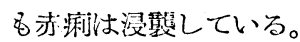

3. 月别にみると， 7,8 月の山は篮々高くなつてきて いるが，冬，春无漸增，1年中発生している。

4. 年令别にみると, 乳幼児及び 3〜8 手の疫痢年令 児に增えている。

5. 流行菌烈は, 24 年志賀菌, 25,6 年駒込BJII 以後 $\mathrm{xD}, 3 \mathrm{a}$ その他漸增。伍年変化してきている。

6. 農村に特ける集四発生の伀播様式は,

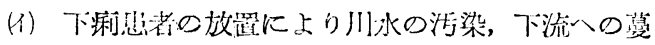
延:

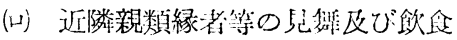

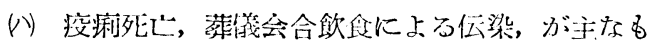
ので㟧ろ。

26. 赤痢保图者の治癔に関する研究（第一報）

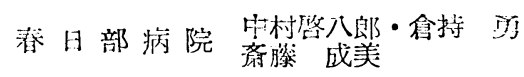

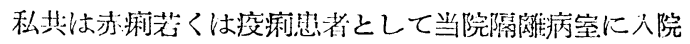
し、クロランフエニコール凶びサイアジン等により治療 し, 症状消失後 2 週間以上に亘つて同, 苗陽性のもの 15 名を対照とし, そらの菂者に, カルバミデン, テー ベン及拮抗性大腸菌療法を行いその経過を観察した。

クロロマイセチンの短期間们肘，及びサイアジンの内 服は，保䔀者の治療に期街出来ない事は，諸家の説と一 致し、テーベンは 1 月 $100 \mathrm{mmg}$ 内服程度では, その効 果は期街出来なかつた。カルバミデンに就てはやや期待 される結果が見られ，今後その投与星，及び投与方法に

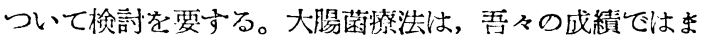
だはつきりした所見を衿められない。

尙カルバミデン，テーベンについて奏険的に薬戍服用

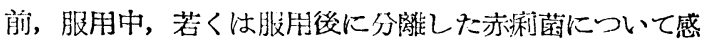
受性:を検査したが，テーベンでは，余り感受性を示さず カルバミデンについては $1 \mathrm{cc} 0.5 \mathrm{mmg}$ では, やや感受 性を示したが, 之は忙らの楽用の使用前, 或は使用後に 


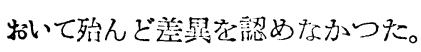

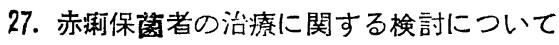

長野 北信病院(束大医局) 膝田進

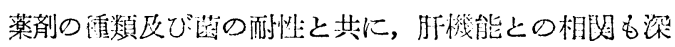
いものがある，私が昨年北信入院の思渚灻対照とし，本 年日本伝染病学会に翢台した通り, 保菌都の肝機能障碍

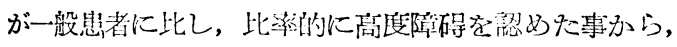

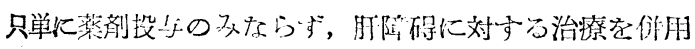

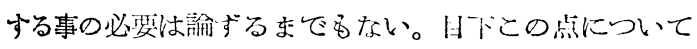
検討して居るが，明年の医学:会に赫告の予定で女る。御 参考运に。

\section{追加}

跑川深生病院 阙 利斑

（19）に対して，血糖は肉体的䞨動，精神的感動，又 食邻により著明な変動を来たし，こ机については充分な 御注意㟧つたと舁 らが，尿糖については測定なされたか もしなされなかつたら，これと同時に尿糖排泄域をも测 定すれば，各種疾思の治潦について，大きな指針となる と思5。

（20）に対して，良湔の尿ヂアスターゼ湘定をなされた

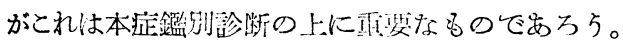

\section{追加新潟 佐渡病院 大崎 完一}

昭和 27 年 8 月刃ミシン, 少イアジン等により 20 日 以上排菌定続けた細菌性赤浰 (駒込BIII) 4例に, 位鸰

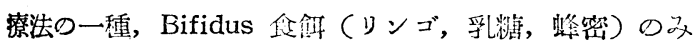

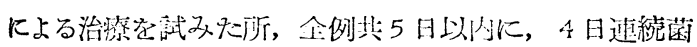
陰性となつた。份 27 年9月より，「パナゾン」を优用

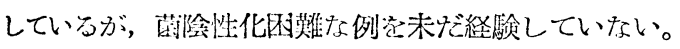

\section{7. 中小学生耳悬咽喉科検診とその治療方法}

岐皋. 昭和病院 网棫 瀑

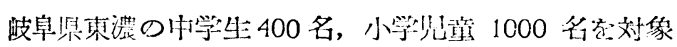
として耳质咽喉科疾思の検查を施行した。

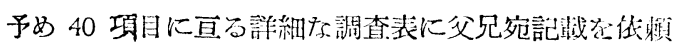
し, そにより耳鼻科的自觉症状を知り, 之と他觉的所兄 とを綜合して疾息の発見に婉めた。

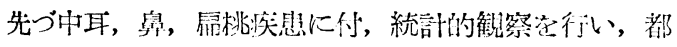

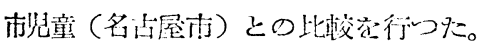

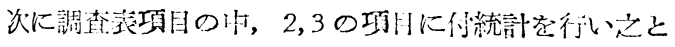
臨林所見，並に疾病との関係について考究した。

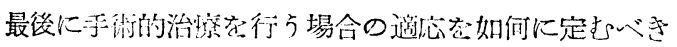
加付梌澍してみ，た。
追加

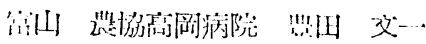

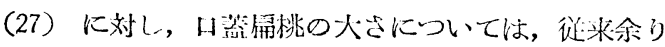

にも無造作に診定されている。埋没部位のととを考えて いない。病巣感染のあるものは埋没性のものが殊に い。アデノイドと吃の関係を言及されたが，吃の成立に ついては精神医学的に检討世秝ばならない。器質的病变

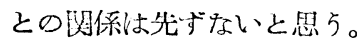

\section{8. 害生虫症之咽喉頭知覺異常}

富山 農協高岡病院 豊田 交一・米丸 年也

局所にさしたる我見なく，咽短頭に知覚異常を訴える 想者が少くない。かかる場合，一応咽喉頭神経症として 片附けられる。しかしそれぞれの症例に於てもつと探究 すべきでなかららか。我々の考光はここに及んだのであ る。ヒステリー，更年期障碍等子考慮に大れつつ，等生 虫との関係を検討したので西る。集団検診に際して 204 名の被梌都中，简些虫のないもの148名，保有者 56 名 につき, 各々咽唯顽知觉罢常のあるbのの 100 分率学出 してみた。前者に於ては $0.7 \%$ ，後者に於ては $23.2 \%$, すなわち，阿者の得隔の極めて大であるのは，寄生虫症 そ咽喉頭知覚異常との間に密接な関係の市るのを想像せ しめるに至つたのである。更に我々は等生虫に因与る，

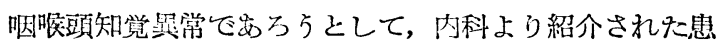
者 18 名につき詳細な梌棠を加えた。列に食道鏡検査を 行つた13 名中，䀝常ないるの6名，限局性食道炎4名，

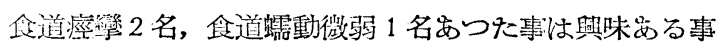
実と言わねばならない。しか子食道粘膜の病理組織学的 検榃に於て渗出性炎症を誌めたのであり,アレルギー性 倾向を感ぜしめるのである。

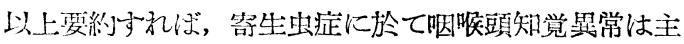
荘微候の一つで市り, その成立機転については, 寄生虫

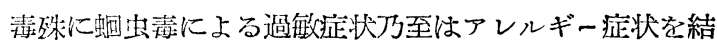
緰づけたいと思らが，その解明について我々は更に検討 を加穴林思 5。

\section{9. 扁桃儤手術後の蒙隔成綪について}

\section{石川 加賀病院 中野 泰孝・宮崎 修}

昭和 26,27 年に的桃剔出術区び切除術を行つを㭧者

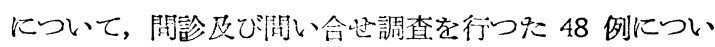
て術後の一般状態学権察し，(1)本手術の結果は全身的局 可的，具に精神的にも良好な影響を与える場合が多い。 (2)健洮状熊の好転, 体重の增加, 感冒, アンギーナの再 炎を防ぎ，(3)耳鼻》タルや虫雷炎の再発がなくなり口 イマチス，鼠疾思，反び難㯖が签快した。(4)淋巴腺炎が 
治り，微熱が出ない様になつた，(5)学生では学業成䋹が 是くなり，性格が明朗になつた。(6)術後の不快症状とし て固頭乾燥感，鼠物感，音声障碍を認めた，音声障碍を 割合に多く訴えているのは，注目すべきではなかららか

\section{0. 粘膜下下甲介切除衍に就て}

\section{栃木 石橋病院 激 重義}

奥閉塞の原因が下甲介の县常に因ると云5場合は，我 々の常に経験する所で，これらに対し，手術的整復を必 要とするととが少くない。との時所謂コンホトミーを以 てするのみでは不充分で，どうしてる粘膜下，下甲介切 除を必要とするととが，しばしば痛感されるのである。 即ちコンホトミーに依り下甲介下端を切除し, 鼻閉は一 応救われるとしても，鼻呼吸の病的状態が改善された訳 ではなく、これが鼻腔, 副悬腔の粘膜機能に及ぼす悪影 響は依然䋨き又手術に上さり出血, 痖着も生じ時には術 後性萎縮性鼻炎を来すととすらある。鼻内気流の状熊， 鼻腔加温加湿能等に対し，下甲介の果す役割を考えれば その粘膜の犠生を選け，支柱組織に過ぎない骨質を除去 して形態を整復し，鼻内気流の正常化を計ることが最も 合理的であるは自明のととである。

この目的のため 1506 年 Stuart-Fow が Submucous Trubinectomy を発薪して以来千集 Ycmckauer Wurdemanu, 榊田, 田中, Zarnico. Winckjei Suliba Horris 松原等が夫ネの術式学発塕し作し Stuart. Low 以下の下甲介粘膜に大きな切開を置くものは出血が多く 且。粘膜骨膜弁の固定が容最でない。开田中，松原らの フ法はあをりにも難しく副損賃多く，目的を達し難いの である。従つてこの手術の普反は殆ど見られず，歴史の 古い割に亦今日の問題であるゆえんるとこにあるのであ る。

抗生物質の発達に上り感染の危険を避け得る現在, 技 術的な簡易化によりこの間題の解決を計るべく，千葉大 北地教授は次の如きう法を考案し，我々もこれにより容 易に目㳘分に所期の目的を達しているので諸家の御批判 を仰ぎたく，ここに発表する次第である。

下甲介骨の形状は図の通り。

手術法 (術式)

型の如き Cocain-Adrenalin の塗布, 消毒の後 $0.5 \%$ Procain2.cc K Ibtt D割合に千倍 Adrenalin を加兄 を麻醉液飞、，下甲介终端，内側面，下縁，中鼻道，兵堤 下甲介外凹面の順に粘膜に浸潤し，下，中，総密道に Cocain Adrenalin のガーゼを抽入し 10 分間待期しガ 一ゼを除いて術を始める。

小光刀を以て鼻堤尔ら下时前端を通り下縁に至る，骨
に卖する約 $2 \mathrm{~cm}$ の切開を置きキリアンの剔離子( 型)

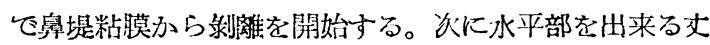
後う迄㩆し，炏で内側面に移る。(Killian の剝晟子厄 1/3前迄は可能である)。更に外四面を注意して出来る丈 後方迄制離し，次に中鼻鏡を插大して，視ながら適当に

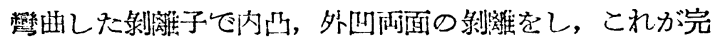
アしたら下縁に移る。この時遊雂縁粘膜を剪刀で $3-5 \mathrm{~mm}$ 切り骨下縁を見得る様にすると容易となる)。

かくして粘膜踿睢が完了したら，ここに始めて肯の摘

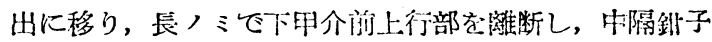
‘县をはさみ，上内う，次で下外うに捻れば後下行部は

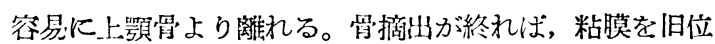
にもどし，下鼻道にタンポンを挿人し，鼻堤及甲介前端 の因創には. Penicillin-Vaselinのガーゼを当て，更に 総究道に Tampon を入れ綿栓して術を終る。

Tampon は型朝除去し，創面上のガーゼは三日目， 下鼻道の Tampon は5 日日に除く。

下甲介は 3〜4 週後に術淤上り容稳小となり，その後

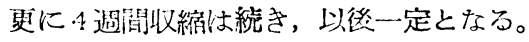

この法により視野は㳂く，㔀離は容易となり，出血子 少く日抗生物質の便用により認むべき偶発事故は未比経 墟しない。

適応は(1肥厚性鼻炎(2)下甲介の形態異常，殊飞奥中隔

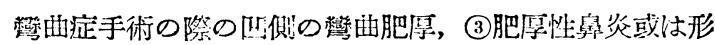

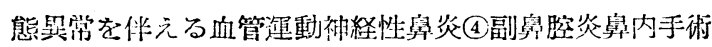
の補叻手段(5)舅咽腔手術の集供手段等て出り，単純性鼻 炎の潔血刑にも有効で第る。

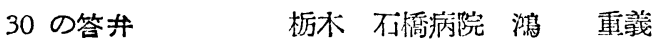

1. 鼻中隔弶的症の場合は勿諭粘膜下開空術を行い, これと同時に粘膜下下甲介手術を行う。

2. コンホトミー上りる粘膜下下甲介纽除炎好む理由 は演説の通り。

3. 保険点数の不利なことは同感である。

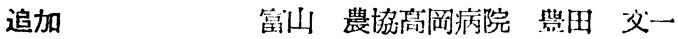

（30）に対し，粘膜下下甲介切除の適当については甲 介骨が中隔に接しているときはいいが，そらでないとき は，今运の甲介切除は拔術的に簡単であるからいいので ないゲろらか。

\section{1. レ線像による前頭洞の統言的観察}

山口周束病院 福田 昌美・松田 昭

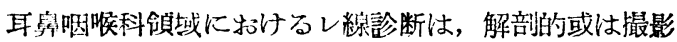
技術に，種々なる倐約を受け診断をトすに常に隔靴择 序の感を禁じ得ないのであるが，レ線湌査は必ず臨床的 


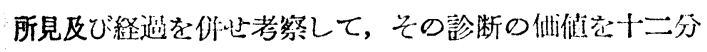
に発揮せねばならないと思ら。

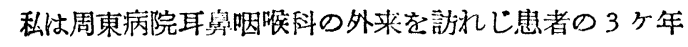
レ線検查者の中で，前頭洞の形態に付いてて統計的観を行 って見たので述べて見度いと思 ら。乙線㭘查を受けな総 数は303名であつた。先ずその中に前頭洞を有する者が 79.87 \%であつた。次にその前頭洞がレ線像に現われた 形態の分類を行い, 前頭洞の大小の分類を行い, 左右対 照形にあるかどらかを観察して見た。そして最後に之等 のレ線像の結果と臨休的所見欧び経過を併せて前頭洞炎 と彭断された者のけで, 主訴と前頭洞炎との関係及び前 頭洞炎と症状との関係及び前頭洞炎と他副鼻炎との関係 について，レ線像のもつ意義に付いて観察を行つた。

結論としては, 以上の結果より副遁腔炎，特に前頭洞 炎の診断はレ線㭘査の補助誩断が絶対に必要にして, 又 その撮影力法る又種々に改善を要し早期钐断に㟧たる事 加千要と思 5 。

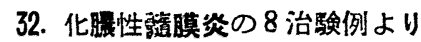

長野 北信病院 桑 譲治 ヘニシリンが自由に使える㥞になつてから，7例耳性

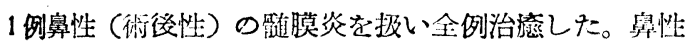
術後性のものの治療には侵入部が不明の為, その閉放を 行わず，最近の交献でもそれで治紫している例が多いが

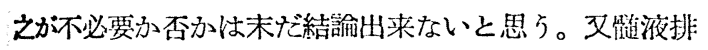
除性持続的に行わずとも全部治摔しているので(文献で も）之は不要になつて来るで女ろう。

化学橑法については, ペニシリン链臆内注入十動注と が効果が著しいが，動注は時に複雓であるのて、もつと

簡単な便用法で治ら好検討やである。

32の追加蜔虫卵を标とせる小児胆石症例

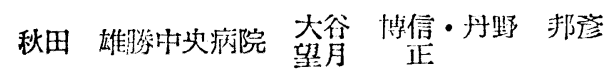

吾々は最近小胃胆不の 2 例に遭遇した。二人とも偶然 にも10年 2 ケ月の男巟であり, いずれも蜔虫卵を核とし ていた。第 1 例は胆汁性腹膜炎は胆蕉蓄䐬症にて手術せ

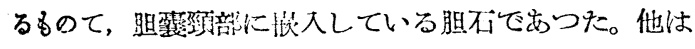
急性胆哑炎として乎術せるととろ, 総輸胆管内に胆不が おつた。

之等の期不の発先年月日を既往症によつて篍ずるに第

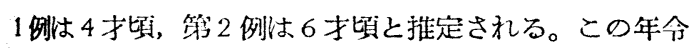

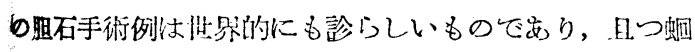
虭が其核をなしていることは, 㖘村の蜔虫駆除に新ら しい間題を提供したことになる。

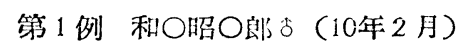

第 2 例 柴○菜○方 (10年 2 月)

\section{3. 農漁村娽人の子宮位置異常と䁏涌とに就いて}

山口 周東病院- 国重 慧

!山口県東部，瀬戸内海に浮儿だ大島，更びそれを取囲 む一群の小島から来院し冒思者 362 名に就き，子管位置 買常，並びに腰痛を吣として調査を行つた。是等患者 は平素農業或は漁業に往事する勤学生活婦人である。又 之に対して平素尙㣫しない婦人 27.4 名を対象とした。

その結果

1）子宮前屈婦人 $62.8 \%$ ，後属婦人 $37.2 \%$ せせり， 対象に比して後屈婦人は $5.3 \%$ 多かつた。

2）経産回数の増加するにつれて後屈婦人ゆ増加する を認めた。而して対象に就いても闹じ結果を得たことよ

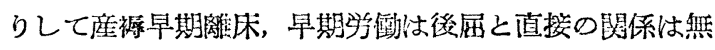
いここを知つた。

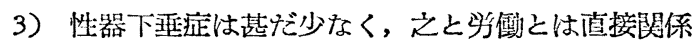
の無いことを想像した。

4）腰痛を訴えた患者は全体の $29.0 \%$ にして対象の 17.1\%比して，多かつた。而して子宮位置異常に基ず くと思考也られるものは腰涌を訴えた思者の $9.5 \%$ 的

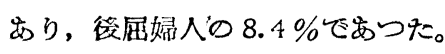

\section{4. 横手地方に於ける妊娠中症}

秋田 平鹿病院 市村 修一

全国卒中死亡率は，常に秋田県は抜群的最高位に虫

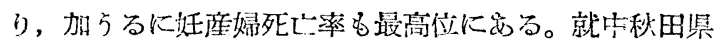

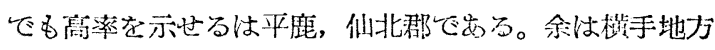
に於ける娃娠中瑇症と女性高血圧, 趆、て卒中死亡との

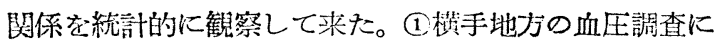
於て女性 30〜50才简血圧頻度は男性のそれ穵淩篗して

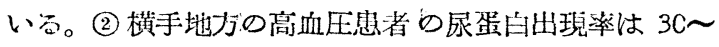
50 才に於て女性に制位である。②既往に妊妮中毒症を 有する者と有せざる者との間には明らかに頻度差が女 る。(4) 30〜50才女性:怯循と最も哭係深き年令にして (1)，(2，の頻度差は少くとも姃艮がそゆ一因となるもの の如く，之に(3)を考光合わすとき，娃娠が女性高血压出

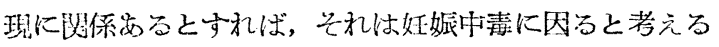
のが妥当であろち。5:卒中死亡率高き県に於ては何れも 30〜50才の死亡率は认性が遙かに優位に每る。

以上上り卒抙死亡率高き目は, 等しく女性卒守死亡率 が 30〜 50 才に於て男性のそれを淩駕している。之は㮖 手地力於て高血压久高血圧照教尿蛋白出現率は 30 50 才江於て女性に限位で品ることに一致している。卒中㱜 亡率に法娠中毒症が大いに閜与しているものの如く， 
その予防は卒中死亡率の低下を来すに大きな役割をなす ๖のであると信ずる。

\section{5. 妊婦高血圧の類症鑑别法と治療}

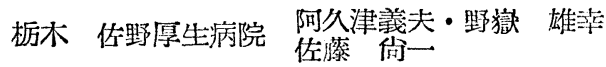

実験的高血圧に関する知見の進歩と。作用機序を罚に する種々の血圧降下剤の登場とは高血圧症の鑑別と治㡜 に飛躍的な進歩を促している。纴㷌高血压につき。私 は以上の如き知見を得ているので埌告する。

1）正常姃婦は妊娠週数を加 5 るに彷い，自律神経造 断剤による血圧降下度学增加するが，中毒症思者では增 加しない。両者の相違は妊娠 20 週前後より知られ, 中 毒症の早期発見に有意㼁で㐫る。

2）中毒症患者の高血圧は自律神経遮断刘では降下乙 ないが, ベレトルム剤によつて降下し，治祭上意義が女 る。

3）ベレトルム剂と自律袖経遮断剂との間に法持㧤 がある。

4）姃婦高血圧症を三大別し，神経性离血圧と，定型 的中毒症と, 中間型とすることが出来る。分娭後, 定型

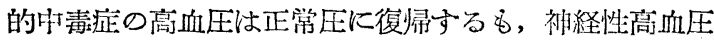
は復帰せず，中間型恃不定で㐫る。

\section{6. “精神予防性 /無痛分娩法の経験}

長野 佐久病院 飯島 昼司・小川 仙一

本法は 1948 年プラトノフ・シュゴーム等の共问研究 に始り，以後ソ連フランス，中国に於て多数実施され， 有効率 85〜95\%と報告されている。

1）本無痛分婏法の理論，本来分婏は疼痛を伴わ奴生 理的現象であり，何故陣痛を訴えるかと云えぱ，第一に 所謂パブロフの言語思索系条件区射により，「分娭炕は

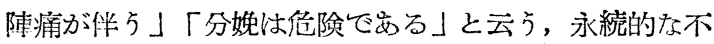

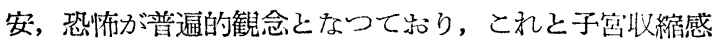
覚, 胎児産道圧迫感喾が条件区射的化結びつき，防厝を 発する一因となる。第二には，このような不安，恐涪の ために，大脳皮質がパブロフ学派の所謂超限制止，这説

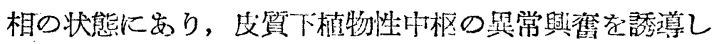
刺战閾が低下し, 微弱な生殖器上りの刺战を疼桷として 感ずるようになると云う。

\section{2). 本無痛分婏法の実施方法}

1）第一の原因たる言語思索系疼痛条件区射袁除去

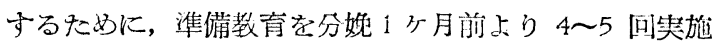
する。文の方法怯(1)本無痛分娩法の内容 (2)生殖器の解 剖, 生理 (3)分㚾過程, 分婏付対与る母体, 胎览の順応

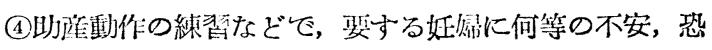
怖もなく分婏にのぞみ得る自信を与えるわけである。

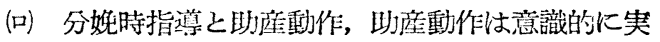
施させることにより，大脳皮質の與丕を維持させ，超限

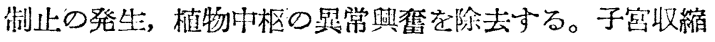
開始と同時に(1)腹式深呼吸を仪維に合わせて施行させる この深呼吸は进だ有効でめる (2不快一緊張感部の圧迫 をする。これも陋で有効で女る。圧迫部は胸椎 Xl, Xl1 の高さより, 分烨進行と共に腰推 $I V, r$, 会除部に下 降して行くようで岁る (3腹部マッサージ。かくて, 排

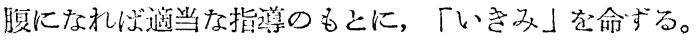
この助险動作寄施中は，医師，看ゴフ，助産婦などが必 ず付添い指導し，姃婦を放置したり，不安を与えるよ5

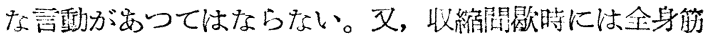
肉志能榣させるととが必裂である。

(4)次に僅か 2 例では山るが，我々の経臨を報告する。

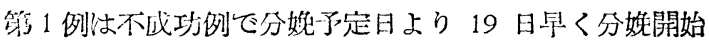
になつたため，準借教育，助医動作練習不十分のため 加腹式深呼吸，不快部圧追により一時的効果は㟧げた が，遂に疼痛を訴えたものである。籍 2 例は，教育，助 産動作練漗完了し，血性分泌後入院したものて，前回の 分婏で、, 不安, 恐怖, 疼痛赽しふつたのであるが, 今 回は非常に安静で出り，疼痽を全く訴えず，収縮時には

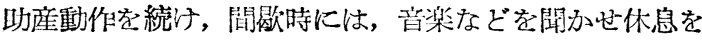
与えた。排覧時, 会陰保護, 会除圧迫のもとに, 第 1 回 の「いきみ」を命ずるに顽部婏出し，符2 回の「いきみ」 を命ずるに肩师部婏出した。この際も全く疼痛を訴えな かつた。勿論以後母，子共に健尿である。本例は成功し た名のと思われる。

\section{追加香川 鸥川彭缸所 池浦 義夫}

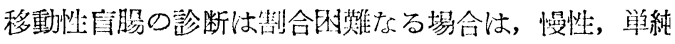
性虫垂炎として䪭断して手術した場合，虫兆に思常な く，移動州底腊の場合が安ること多し。

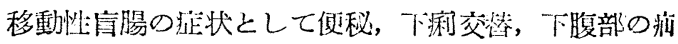
瘦, 腰痛, 定位によつて右腎下野を触診すれば有紧下野

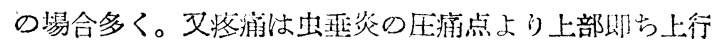
晹の中間に压瘦点就こと多し。

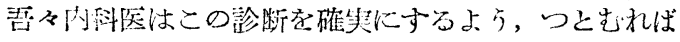
一生苦しむ思者を救い得るるり信す。

追加秋田平鹿䓑院市村修一

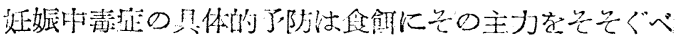

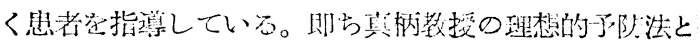

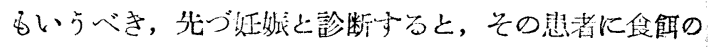

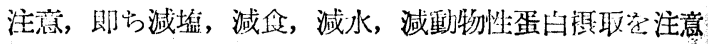


し，弤娠後半期になれば毎週一定の日を定めて体重を测 定させ, 増加量により一層食餌の注意を戦重にさす, そ れでる中毒症の発現を来さば安静，出来れば入院加療を す寸める。

\section{追加蝮咬症のハイポ靜注療法}

蝮咬症の 13 才男子に3日間ハイポの静注を施行し, 7日で完全に治療せしめた症例を報告し, ハイポの解毒 機転について述べた。

\section{追加}

\section{血圧連続側定に就いて}

新舄 長岡中央病院 鈴木 宗 基碟血圧決定に 対する 連続測定の 意義を知らんとし て, 正常血圧者に於て種ふの状態からの連続 10 回血圧 测定を施行，之と安静のみによる血圧下降とを比較考察 し, 次の如き結論を得た。

血圧測定時可及的正しい值を得るためには，一定時間 安静仰臥せしむる事は勿論必亚であるが，更にマンシエ ットを卷く事の影等並びに血圧測定による器峨的及精神 的影響殊に血管運動神経への影響も大いに洘虑する必要 がある様である。而して是等の影㗽を可及的短時間に除 去するためには，速続測定法が良く，測定回数は 10 问 が適当ではないかと考元られる。

\section{7. ナイロン =リングの使用経験例について}

長野 位久病院 领島 宣司・小川仙一

I. 私共は, 昭和 27 年 10 月以降,太田式ナイ リングの追試を 56 名に行い，比較的苌い成繢を得てい る。

II. (1) 成功例一 $64.3 \%$ (副作用なく感謝的なもの $37.5 \%$ ，輕度の障害を訴えるが除去するに至ら程度の ○の21.4\%，弤娠希望のため除去したもの5.4\%)

(2) 失敗例一 $19.6 \%$ (弤妮したもの $7.1 \%$, 副作 用一带下, 腰痛, 下腹痛, 不正出血一のため除 去したもの $7.1 \%$ ，自然脱出したもの5.4\%)

(3) 消息不明のもの- $16.1 \%$

（4）战功例について詳細に調へててみると，月経持続 月経量, 月経痛, 菬下, 腰部反び下腹部落痛は多少 增強する傾向が女るが，各障碍は插大後 2 乃至 3 ケ 月迄にひどく，之れ以後は輕減するよ5に思れれ る。

III. ナイトンニリングは手数がかからず，又費用もや おく，且つ確実性に於ても是好の成績を挙げているが， 一方では副作用を来しやすい欠点がある。しかし此等障 淂は一般に輕度で，㛿人自身が苦痛と感ずる場合は比較 的少く，人工弤娠中絶術に伴5䌘害を考える時，ナイロ
ンニリングは，農村に於ては試みられてよい一つの受胎 調節法でると思う。

\section{8. 農山村及び都会地婦人の優生手術之} その後の経過について

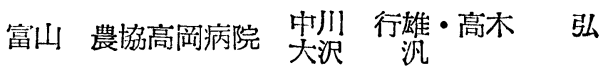

吾々は昭和 23 年 9 月より 28 年 5 月迄に, 農山村婦人 (A) 152 名, 都会地婦人 (C) 115 名に優生手術を行い 次の如き結果を得た。

1). 年龄別, A では 35〜39 才が $40.8 \%$ を占め平均 34.4才Cでは 30〜34 才が $40.4 \%$ を占め, 平均 35.7 才 である。

2）弤娠回数，Aでは 5 回が $16.4 \%$ を示し，平均5.9 回，Cでは 5 回が $21.7 \%$ 示し，平均 5.1 回である。

3）生存览数，Aでは 3 名と 4 名が夫々 $22.4 \%$ て平 均 4.0 名, Cでは 3 名と 4 名が夫々 $24.4 \%$ で平均 4.0 名 である。

4) 人工妊娠中絶回数，Aでは 1 回59.2\%末経験 30.2 \%,Cでは 1 回 47.8\%, 未経験 35.7\%である。

5）適応症，再区分共多産栄養低下が最も多く，次い で弤娠中毒症, 呼吸器症息である。

6）作用手術，人工妊娠中絶はAでは 64.5\%，Cでは $57.7 \%$, その他流库等弤娠時に多い。

優生手術後の経過について, 術後の状況を間合せ $\mathrm{A}$ 125 名, C95名の回營を得た。

1) 年路別, Aでは 40〜 45 才が $32.0 \%$ を占め平均 38.7 才, Cでは 35〜39 才が42.1\%を占め平均 36.8才 である。

2）姃娠回数，Aでは 6 回が $18.4 \%$ を示し平均 5.6 回，Cでは5回が 28.4 \%を示し望均 4.9 回である。 3）生存照数，Aでは 4 名が $23.2 \%$ で平均 4.0 名, Cでは 3 名が $25.3 \%$ \%平均 3.4 名である。

4）月経について，Aでは変ら好 $37.6 \%$, 順調にな つた $23 \%$ ，Cでは変らぬ2 $44.6 \%$, 順調になつた $24 \%$ にある。

5）身体の暴常について，Aて恃異常なし $42.4 \%$, Cでは $49 \%$ \%をる。

6）性感について，Aでは琾常めり $7.2 \%$ Cでは $9.3 \%$ にら不感症を訴えている。

7）術後子供が欲しくなつたか, 望さものAに6名, Cに 7 名あり。

8）術後弤诪の有無，Cに1名安り，流座を起し来院

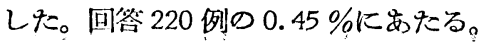


以上の結果に基いて2,3の事項につき，吾々の見解芣 述べんとするすのである。

39. マドレーネル氏法による卵管結柇後子宮外

\section{妊娠を起した 1 例について}

杤木 石楅病院 河野 政昌

昭和 25 年 4 月，開腹にてマドレーネル氏法による開 腹畉管不弤術を行い，以後 2 ケ年 9 ケ月間不弤に経過し 本年 2 月 16 日外坻の疑いにて開腹手術を行い，畉管嘭 大部弤娠破裂で琼つた 1 例を経験したので報告する。

患者は 37 才の主婦で（家族歴には特記事項なし）既 往妊娠は $10 \times$, 正常分婏 $5 \times$, 自然流庭 $3 \times$, aus $2 \times$ 行 つている。

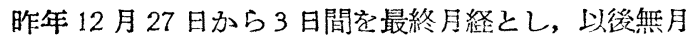
経となつたが，つ尚り症状は訴えていない。以後 2 月 11 日迄ときに下腹部痛があつたが，其の他に罚常を認めな かつた。2月12日性器出血市り，息者は月経と思つて いた所，14日の朝輕い右下腹部痛か起り外来を訪れた。 患者を見るに，外陰部に異常なく，腟分泌物は血性やや 多く，外子宮口は閉塞していた。

子宮は前傾屈で大きさ手拳大, 硬度は顿, 右附属器に

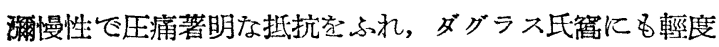
の抵抗庄ふれた。左附属器は是常を諗めず，ついでダグ ラス腔穿刺を行つた所, Cá2.e.e. 凝固を起さない偣赤 色血液を認む。

更に Probe Aus を行つたが䄉毛を認めない。

以上にて，一応外妊の疑いにて手術永儿としたが，腹 痛もなく出血も止まり，患者希望も岁つたので, 州宅 を許し安静を命じたが，16日午後に至り，再び激しい右 下腹部痛あり嘔吐数回, 加えて念性筫血症状を呈したの で, 即日手術を行つた。

手術時所見 : 局麻に上り腹腔学開くと, 腹腔内には多

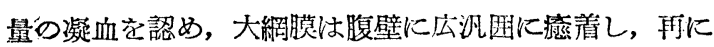
右卵管とも狂着を起していた。

子宮は前倾屈大きさ手拳大, 硬度㳄やや立血す。右侧 卵管は膨大部と㹨部との中間でロ状にながり，この部に

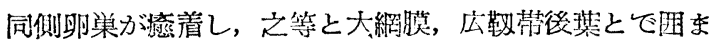
れた大きさ略々貕㥸大の血腫を形战して居た。

卵管の夫さは略々正常で充血し，四管絲は開放して居 り，瞦大部は超母指顽犬に腫脹し，ここに破裂口を総め た。

作し前の手術て卵管をコッへルにて区挫結紮したと思 われる個所には，外観上何等变化觉愁めなかつた。

卵巣表面には黄体形成らしき部位を認めた。 左侧卵管は網膜との瘾着なく，太さは通常の半分位て
長さもやや短かく，光の手術で圧挫結禁したと思われる 個所《長さ $0.5 \mathrm{~cm}$ にわたり, 菲薄なる膜様を呈して居 た。

同側畉紧は正常よりもやや小さく，堇体形成は認めな からた。術後経過舆好にして退院に至つた。

総括

本、例は腹式に，マドレーネル氏法眀管不妊術を行なつ た後，2ケ年 9 ケ閪にわたつて，何等認むべき症状も なく, 不弤に経過した 37 才の家婦に於て, 諗められた

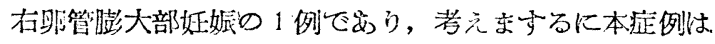
マドレーネル氏手術にさいし, 生挫が不完全でありて,

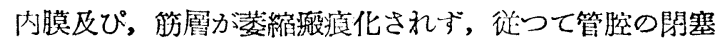
が不全であつたため，精子は，通過したが，受精畉の通 過が妨げられて，瞦大部炡妮となつたものと思水れる。

附 記

1）卵思老登育舅常

2) 輸送路の罢常延長

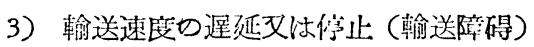

(a) 畉翰送動力の不全又は消失 (蠕動 䫖毛傕動)

(b) 卵輸送路の疏通障碍

（1）卵管腔の狭サク无は閉塞

(1) 粘膜スウ壁ゆ療着及分泌物

(ㅁ) 畉管の属折, 捻転, 圧縮

(》) 手術による

（2）盲端纪終る卵管壁の副管 Wlth の郋管上皮 管の筋肉内分枝

\section{0. 片麻㿉光伴う急性骨箈性白血病の 1 例}

長野 贸和病院 菘息 迨雄

25 才, 只, 昭和 28 年 7 月 2 日念に意識润濁し, 4 日に左片林澋を来乙て入院。入院時体温 $38.6^{\circ} \mathrm{C}$, 顔面”

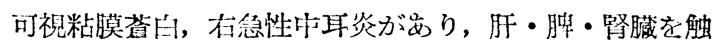
知しない。リンパ腺㹸张なく，出血倐向を認めない。赤 血球 85 厅，血色素 $18 \%$, 松球 84000 , 思状赤血球 $24 \%$

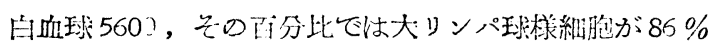

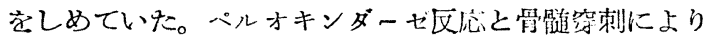

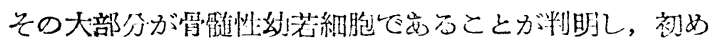

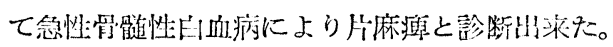

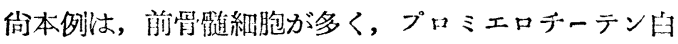
血病の型を示していた。

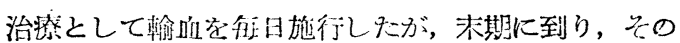
為に悪寒高熹を将したように思われた。 


\section{1. 白血病例について}

杤不 下都賀病院 黑管了 瑞枝 白血病 4 例を経験したのて報点する。第 1 例 39 才女

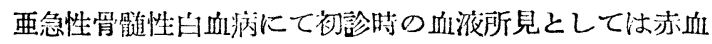
球 131 万, 白血球 8300 , 血色素量 $35 \%$, 好中性前常骨道

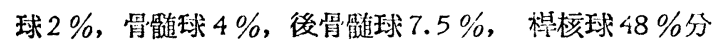
節核球 $23 \%$, 大淋巴球 $1.5 \%$, 小淋巴球 $9.5 \%$, 好 酸球 0 ., 好塩基球 0 ., 単球 $4.5 \%$, 赤芽球 200 ケ中 2 ヶ, 血小板 114000 , 出血時間 2 分 30 秒, 血液凝固開始

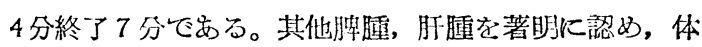
温は37度から時には39底の不規則な熱型を示した，こ

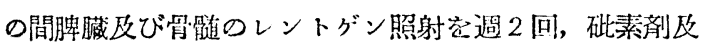
び還元鉄の洹増投与, 輸血l, ヂギタリス某末内服を行つ たところ約 3 月後、には, 未梢血液中の幼弱血血球は完全 に消失乙，赤，白，血球数与正常佂に復し約 1 年㷋に何等

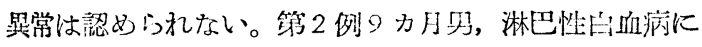

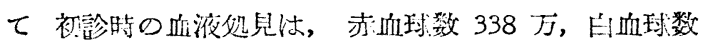
13200 血色素琵 $65 \%$ ，㩐核球 $1 \%$, 分節校球 $17 \%$, 淋巴球 $77 \%$, 好酸球 $3 \%$, 好嫶基球0., 单球 $2 \%$ 出血

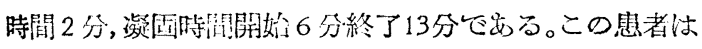
前胸部, 腰部, 下䏠に腤紫色の大豆大から畹豆大の硬結が 認められ脾䐠も左肋骨弓下 $4.2 \mathrm{~cm}$ 触知した。体温は 37 度, 通院にて聘臟のレントゲン照射, カチーフの皮下注 射を行い, 約 9 力月後には脾蔵は肋骨引内に僅かに触れ 皮下の硬結は全部消退し末悄血液処見は，赤血球 386 万 白血球 8200 ，血色素鼠 $72 \%$ 血液像は禑核球 $1 \%$ ，分節 核球 $17 \%$, 淋巴球 $77 \%$, 好酸球 $3 \%$, 好㙁基球 0 , 単 球 $2 \%$, て現在は経過観察中である。第 3 例 1 年 11 ケ 月男, 淋巴性白血病にて, 両頸部, 顎下部淋巴腺は何れ

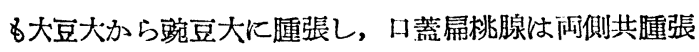
ᄂ, 肝臓 $4 \mathrm{Cm}$, 脾臟 $4.5 \mathrm{Cm}$ 助首弓下に触知, 末梢血 液検査怯, 赤血球 182 万, 白血球 21600 , 血色素量 $35 \%$ 血液像は，桿核球 $5 \%$, 分節核球 $11 \%$, 淋巴球 $81 \%$, 好酸球 $1 \%$, 好䅉基球 0 , 単球 $2 \%$ て市る。通院にて 脾矌のレントゲン照射, ナイトロシー注射及び血液注射 を行い12 日後には白血球数 8900 血液像は，桿核球 $5 \%$ 分節核球 $10 \%$, 淋巴球 $83 \%$ ，好酸球 $1 \%$ ，好塩基球 0 . 単球 $1 \%$ となり，一般状態も岂好となつてきたが，以来 通院しないので遠隔成績は不明である。

第 4 例，40 才女，亜急性淋巴性白血病，初診時の血 液処見は，赤血球 257 万，白血球 28500 ，血色素量 $48 \%$ 血液像，好中性棉核球 $4 \%$, 分節核球 $5 \%$, 淋巴芽球0. 大及び小淋巴球 $50.5 \%$, 好酸球 $0 \%$, 単球 $0.5 \%$,
赤茅球 0.，血小板 30840 ，出血時間 40 分以上で女る

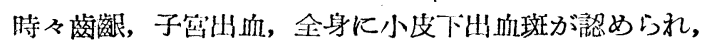

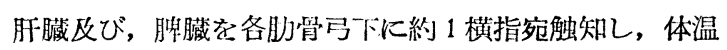
は 37.5 度から 38 度を上下し, 入院に依りレントゲン 照射，還元鉄反び䂤素剂の漸増療法艺行い，末梢血液処 見及び一般状態は，第 17 病日女たりより好転してきた が, 約 1 週間後には再び増悪の傾向を生じてきたため, ナイトロシンを使用したが，胸内苦悶を訴えた為中止し 右肋膜窒内及び右侧腹部に多量の出血を生じ，99 日目 に死亡した。

\section{2. 血液病の 2 剅檢例}

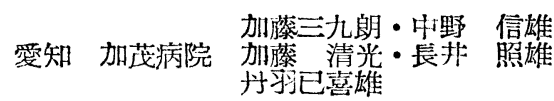

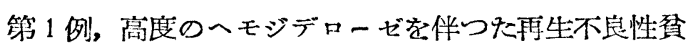
血 28 才の男子。死亡前 5 五カ年間に数回にわたつて出 血性淁因, 高熱, 頚血の発症䒚見, 治療により寛解を見 つつも段々に覀化し, 死亡した。この 5 カ年間に10450cc の輸血を受けている。

剖検上骨髄には再生不良性㽝血を裹づけるアプラジア を衿める。肝臓, 嘩藏, 腹部リンパ腺が高度のへモジデ リン沈着め為褐色を呈して居り,かつ該藏器には著明な る線維化がみられた。骨䯣, 睥缄のへモジデリン沈着は は極くわづかに認められたに過ぎない。小腸䄉毛は肉眼 時に褐色を呈する程てはない。

本例は再生不良性会血に, 輸血によるへモジデローゼ を合欮たものと考える。

第 2 例, 大なる縦隔腫瘍を有した白血病 37 才の男子 死亡前 40 日のX線写真にて, 右縦隔の陰影と右胸水を 認め, 胸水沈㴡中に大型の異常細胞を認めた, 白血球数 は経過の途中より急激に增加し始め, 正常数より 37 万 に迄至り死亡した。

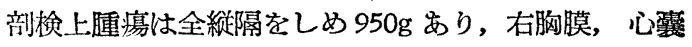
に浸潤している。リンパ腺腫脹, 肝, 睥腫があり, 組織 学的に各臟器に白血病細胞の浸潤を認めた。

本例は亚白血病て縦隔腫瘳を有したものが，末期に急 性白血病の像を呈したものと考える。

\section{3. 加茂病院にて剖検せる 45 症例}

$$
\text { 愛知 加茂病院 } \begin{aligned}
& \text { 妿藤苗実代司・朗・藤 } \\
& \text { 福岡 光雄 }
\end{aligned}
$$

我々は開院以来 6 年間に 45 例の剖検施行，これは農 村に於ける唒理解と交道堨所の不便なる状況の下に行わ 


\section{れたものである。}

しかし我々は臨床診断站治撩ゆ 正確を期するために は, 剖検のぜひ必要なる事を痛感し，剖検例の増加に極 力努力して居ります。

倘病理所見については，名大宮川教授指導の下に肉腿 立組織学的に綿密に行つて居ります。剖検例を, 死因に 依つて分類すると，心蔵 15 例，脾畽 9 例，腹膜炎 4 例， 腸チフス 3 例, 血夜病 3 例, 結核 2 例, 腎荿 3 例, 其の 他 6 例合計 45 例であります。

臨床钐断と剖検㟝断の相遠は, 一致せるもの 30 例, 他疾患の合伷せるもの3 例, 一致せざるもの 12 例をあ りました。

次に粟粒結核及結核性脳膜炎を思わせた 2 症例につい て,スライドを以て臨床所見, 剖検所見組織学的所見を 説明，肺瘦及其の転移であつた事を述べた。

\section{4. 流行性筋痛之思われる症例}

\section{長野 佐久病院 三井善之助・竹添 和英}

昨年夏 5 6 月頃から, 私たちの病院に長野県南佐久 郡, 南相木村 (標高 1,200 , 人口 260)（スライド 1 ) から，長期間にわたつて，通院してくる患者 3 名が，類 似の症状を呈て居るのに，まづ奇異の感がしたのすが， 之等の㭧者言によれば，同村には自分等の他にも同様 の症状を呈する患者がそらとら居るとの事化より，その 中の 2 名を入院させ,くわしく検査しました。

この患者は，何れも25 才以下の若い人て，主要な症 状は,スライド 2 に示します様に, 胸痛, 背痛, 腰痛,

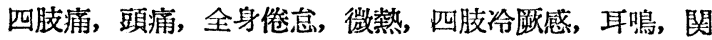
節痛, 発汗, 食思不振, 脱力感, 不眠, 悪心等厄, 殊飞 下胸, 上腹痛が特徵であり,よくしらべると, 腰痛, 大

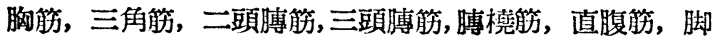
腸筋その他飞筋痛がありました。微熱長く続き胸背筋, 全身僚急等があつて，まつ胸部し線の透視撮影をします と, 肋膜瘾着も肥厚もなく, 肺化も全く变化むりません し，3名中，2名は「ッ」区応は陰性でありましたし， 血沈が常に正常値を示しました。2名の中 1 名に極く一 過性に輕度の白血病增多症を認めた他は, 白血球数は略 正常値を示しました。血圧が 2 名とも極く僅かに上昇し て居をした。

外来治療〔仲々輕快しないのて，入院精査の上，更に 治療を加えましたが，ザルソー刻，グレラン，ボカイン 静注, テプロン, イミダทン, シンコルタ, レスタミン 注射及び超短波, 脳下垂体移植, 冷蔵皮膚移植等を試 ※ましたが，大方は無効厄ありました。
此の様な状態で，之の疾患が如何なる種類のものか， いぶかつて居ました所, 最近交献て「流行性筋痛」と云 らのを発見し，食いちがつて居る点もいくつかあるの でありますが，一応類似点を求めてもよいのではないか と思いました。流行性筋痛 Epidemic myalgie Epide -mic pleuro dyniaは 1872 年初めて, ルルエーで報 出され，その後スカンヂナビアでは相当注目され，英国 ‘゙はボルンホルム病,米国では Deuil's grip など呼ばれ ていぬしたが，日本でも最近北本，日野，藤井等の報告 がありました。発熱, 上腹下胸痛, 食思不振輕度の吧頭 痛を主とし，集団的に発生するのであるが，散発的の事 ああると云われる。1947 年 Dalldorf Polio K似た息 者から一新ビールス Coxsaekis Virus を分離し，所謂 流行性筋痛はこのVirusにより惹起されると云つた。 然しながら䓯起される疾病は，単一でなく, Nonparal一 ydic Poliomgchtis Pleurodynia, Herpanjina Aseptic meningsis Summer Grip などがあげられ ています。

内山，酒答氏等の報台では，7 日前後の短期間の弛張熱 と食思不振を主とし，輕い頭痛を訴え，著明な白血球減 少と血沈促進を示した51名の発生例をあげ，その中から Coxsackie Virusを分離したと報告して居ますが，之 の中でPleurodyniaのあつたのは唯 3 名に過ぎなかつた と云つて居ます, この様に Coxsackie Visus の起す病 变は色々複雑であります。日野氏自自家経験例から，本 Epidemic myalgia が, 日本にも存在寸るのではないか と云つて特门れる。我々の遭遇した症例について，我令 は不幸にして、Virus 学的検萦を行わなかつたのであり 経過の点, 血沱, 発熱の点など若干の疑間の点はありま すが，一応この粎な疾病を疑つてもよいのではないかと 思 5次第です。

\section{5. 整形外科領域より見た高知県農漁村の 䁏背痛について}

高知 高陵病院 陸 四郎

昭和 27 年 1 月1日より, 昭和28年7月31日运に当病院 整形外科，外科を受敦した患者の内，整形外科的疾患を 統計的に観察した所, 腰背部打撲症, 变形性脊推炎, 推 間軟骨へルニヤ，春推骨折等，山村漁村の学働に起因す ると考えられる所の，腰背痛を主訴とするものが圧倒的 に多かつた。この腰背痛を主訴とする㭧者に対し，整形 外科領域に属するものりみについて, 各疾患別に分類観 察し, 刃年令, 性, 学働状態, 生活摆境, 更に当地方の 地理的特殊条件等の面少ら，批判考察を加へると共に， 治潦の一端を述べる。 


\section{6. テラマイシン気管内注入による肺壊瘨の}

\section{2 治験例}

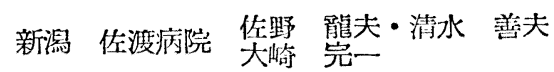

肺壊疽の治然に於て，抗生物質の占める役制の大なる は, 周知の如くであっ。この際発病上り治奖開始治の期 間の短い程，艮結果の得られることも甡に指摘されてい る。即ち可及的早期にペニシリンり気管内注大を実施す

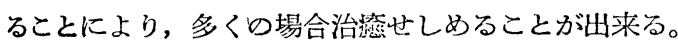
然しペニシリンのみで治虚しない例に対しては，他の抗 生物貿中ではテラマイシンの気管内注入が最も碳れるい るととも，諸笩の報告する酒で女る，我々は最初，ペニ シリン気管内注入により，㱠んど効棵の見られなかつた 1 例にテラマイシンを使用, 文他の 1 例仙, ペニシリ ンにスプラーゼを混合するととにより，良結策を得たの 厄報告する。

第 1 例山幾 $\bigcirc 62$ 才,

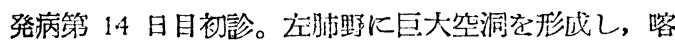
啖仙 400 万至 500 c.c., $38^{\circ} \mathrm{C}$ に及ぶ発熱安り゚ ペニシリ

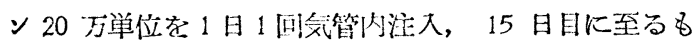
200 万至 300 c.c. の喀览排出安り, 上つて注射用テラマ イシン $5 \mathrm{Cmg}$ の 1 日 1 回父管内注入を開始，14 回の注入 により，喀啖殆んど出なくなり，肺病奬も著昭に改善さ

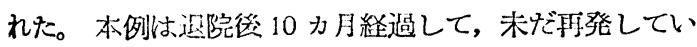
ない。

第2例中OイO 44才, 9 ,

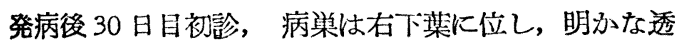
亮像を認めない。直ちにペニシリン 10 万算位，1日 1 回気管内注入を開始，サイアジン $6 \mathrm{~g}$ 内服を作用，20回

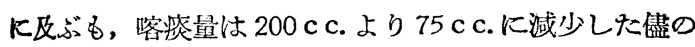
状態を持続するに至り，パニシリンを20 万增量せるる 变化なく、スプラーゼを1回 5,000V.u.M. 混大せるに 翌日より藷明に峈痰減少し，副作用は全く認められず，

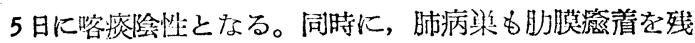
すのみで, 殆んど消失した。ヒアルロニダーゼを抗生物 質と共に使用することは既に試みられているが，肺壊瘨 に対しての効果についての報告を兒ない。

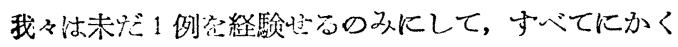
○如く著効を見るか，否かは绱不明なるも，一床ペリシ リンイスプラーゼを加えて気管内注入忩試みるととを提 唱する。

\section{7. 人血济 21 グロブリンによる麻疹の予防} 茨城 協同病院 宇津
今年の麻疮の流行に際して，人血清 21 グロブリンを 予防に用いた。

1. 予防注射をした例数は 34 例, その5ち不発症は 25 例, 発症は 9 例て, 䂆方成績は $71 \%$ となつた。

2. 然し麻疹㭧者が同胞飞安つたり，隣家に安つた場 合，即ち感染の機会が多い、例では予防成績は 50 \%とな つた。

3. 感染の機会の少い例では, 䂆防成績は $90 \%$ とな つた。

4. 使用血清量はプロキロ 0.2c.c. で, 副作用として 特別のものは認められなかつた。

5. 発症した例は何れも輕く, 合侀症は 1 例もなから \%。

6. 便用血清量を增加すれば，予防成績は更に良好と なると思われる。

\section{8. 気氨内麻酔の経験}

長野 佐久病院 佐々木真爾

気管内麻醉を使用した，肺葉切除任か胸部上腹部 12 例について, 前麻醉, 䆃入麻酩維持等について述べ, 更に麻酔経過は局所麻醉に比べて順調であることを示し た。

更に本麻醉法は設備，人員等の点よりの苦心を述べた が，農村病院に䄧いても，早く自由に使える日の来るこ とをのどむ。

\section{9. 初期人工姙娠中絶に対する Surifal Sosium の応用に就て}

杤木 下都賀病院 加藤 彰

初期人工弤娠中絶 30 例に, Sutital Suodium 製郕た るアミパンソーダを使用し，次の如き結果を得た。

1. 就眠量, 平均 $6.2 \mathrm{cc}$, 最少 $4 \mathrm{cc}$, 最高 $8 \mathrm{cc}$ である

2. 持続時間, 最短 6 分, 最長 14 分, 平均 8 分飞市 る,

3. 血圧, 值前, 直後に測定, 下降せるすのは 4 例, 不变が 6 例，上昇， 20 例。

4. 脉膞数, 減少せるもの 8 例, 他は多少増加してい 万。

5. 呼吸数は，大部分が柾少数增加した。

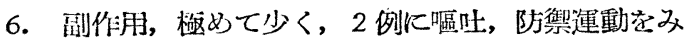
た，他には譛むべき副作用はなかつた。

\section{Mercurochrome 皮圆炎の 3 例}

杤木 石橋病院 沜 重義

Mercurochrome は 1919 年 Yoüug 等の創製にかか り，大正末期以来，本邦にも紹介され，公く用いられる 
に至つたが，これに因る皮膚炎は，交献上極めて稀であ る。最近相次で 3 例を経験したので報告する。

第 1 例，12才男子，数年前 Mercuiro chrome で, 皮膚炎を起したことを記憶して括り，次後使用しなか つたが，昨年 3 月上顎洞線維腫の手術に際し，術野に Mercnro-chrome を淮布した所, 24時間後, この部に 一致して広沉な潮紅が現われ，中忙哭数の小丘疹を生じ 強い搔接を伴つた。清拭不充分の場所では，4日目に水 泡を生ずる程で品つた。1 週後, 発赤腫脹は消失, 水泡 は乾燥し，落序色素沈著を来し，2週後落序は終了， 3 週後色素沈著西消失した。

3 力月後, Patch-test を行い, Mercuro-chrome 飞 よつてはその漕度に応じ, 夫々の強度の境界鮮明な, 発 赤睡脹を生し，水銀軟霄では，局方の百倍稀㰤のもので

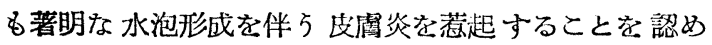
た。対照の esrauin や, Vaselin では, 全然区応が見ら れなかつた。

第 2 例，22 才女子，15 才毛虫にから゙れ，18 才游水 後，2３日乚て顔面局等に水泡を伴亏激しい皮膚炎来 し, 又その頃化粧品のクリームを变えた所，やはり2〜3 日後, 発赤腫脹を生じたことがあつた。伊し, Mercürochromeを用いても，刺战症状を呈したことはなかつ た，本年 1 月，中耳炎，手術に際し， Mercurochrome 塗布後 24 時間で搔竧を感じ，48時間後小水泡を伴万境 界鮮明な皮膚炎を生し，やはり施皮形成色素沈着の後， 2 週後治癒した発症後間もなく，Patch-test を施行し た所，水銀軟㥜では小水泡を伴 万発赤腫脹を来したが， Mercurochrome 厄恃预期汉し，何等の反応を示さな かつた。

第 3 例，17才女子，同じく本年 5 月中耳炎手術に際し

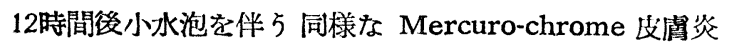
を惹起した。この症例ては, Patch-testにより, Mercu -rochrome に因ることを確認し得た。これも約 2 週間 て完全治痖した。

以上 3 例とも，12〜48時間後に，梁布部に一致した発 赤腫脹を生し，水泡形成を伴い，泇皮脱落，色素沈着の 後数週間て治瘾する。涩布せぬ部との境界は，極めて 鮮明で，又完全に拭き取つてしてしまつた部位には起ら ず, 定状発現後の Mercuroc-hrome 除去が充分でなか つた所程強く，且長く経過する。

何れも，手術に際して生じたのであるが，被䧻の有無 血液創液或は, 発汗による刺㦸等とは特別な関係が認め られない様である。

又 3 例とも，水銀特異体貿と認められるが，第 1 例と
第3 例は， Mercuro-chrome に対する過敌性に基ゔく あので女るが，第2 例以過去に於て, Mercuro-chrome “何等の罢常を呈せず，又 Patch-test によつても汶応 を見なのて，Mercuro-chrome の特異体質とは認め難 い。作し，その症状経過上り見て，Mercuro-chromeに 原因したことは明らかで, 特殊な条件の下に，一时的に 過敏の状態にあつたと老えるべきであろら。

Mercuro-chrome 支覤炎は, 欧米に於て10例たらず の記載を見るのみで，本邦にては寡聞未の報台に接

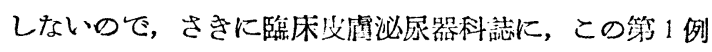
を報䈇したが，その後更に，2例を得たので玆に追加報 告した次籍である, この棁に, 最近頻繁に生じたことか

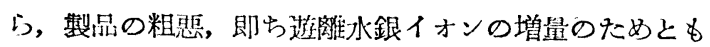
考へられるが, 上記 3 例から見て, むしろ否定的であつ て, 従つて, 案外交献に現はれね症例が多いのではない かと思われるので, 諸家の御追加御教示を爿きたいと存 ボる。

\section{1. 佐久病院に於ける逆性石醶の使用について}

長野 佐久病院 岡部之も・井出花代

手術時の手指消毒の簡略化のため, 当院外科に於ては 本年5月より逆性石䚙を使用し良成績を得ているが，之 に先立ち 2〜3 の実験を致しました。実験方法と致しま

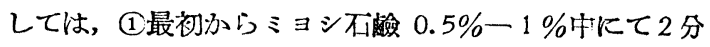

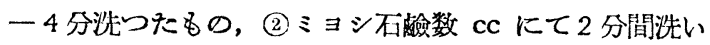
後 0.5\%ー1\%の液中にて沙つたもの, (3)普通不醶 3 分 間更にミョシ不羷液 $0.5 \%-1 \%$ 液中にて 2 分一 3 分洗 つたもの, このけで私達の一番適当と思われ又一番無菌 的に安心して出来るものとして, 第 2 の方法を使用して 物ります。培盖方法としては手洗後一予め, 洗面器中 $50 \mathrm{ccc}$ の滅菌水を用意し，これにて良く，ブラシを用いて，洗 いとの水をピペットにて $1 \mathrm{cc}$ 取り, 寒天平板培地に注入 $37^{\circ} \mathrm{C}, 24$ 時間フラン器にて培養した。文長時間にわた る手術時中の手洗は，0.25\%，溶液を使用して特ります この様にして, 逆性石蝓を用いれば手洗も短縮出来, 消 毒効果も強力であり，又無臭無刺䈅性にて，経済的にも 從来行つたフエールベリンゲル氏法より安く, 種々の利 点よりミヨシ逆性石襝を用いる事を妥当と考只る。

\section{2. 術後排尿障蔓の克服について}

\section{長野 佐久病院 看護婦 飯息 秀子}

病院勤務の看護婦として, 手術患者の看護こそ, 難办 しくヌその容態観察には日頃より责任を感じて括ります たまたま私達佐久病院で, 術後の排层障害患者が多く この事は患者にとつて甚しく不快なばかりでなく，賃の 
痛みを増す原因ともなりますのて, 看護婦の立場からこ の克服のために次の調查を致しました。

スライドこの衰は, 昭和 27 年 6 月より 28 年 5 月まて

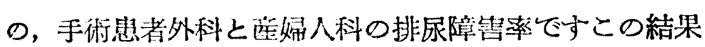
外科の $20.6 \%$ に対し，産婦人科では $57.6 \%$ 上云 $5 大 き$ な差が出て牤り，更に下の性別玟でも，女性の場合の排 尿障㕩がはつきりと現われて呿ります。スライド第二表

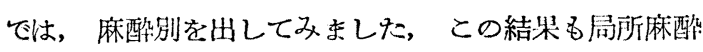
(18.3\%) 上りも，腰推麻酔 $(29.6 \%)$ の方が障䙵率が 多い事が出て括ります。更に下の手術部位别に出してみ ました所, 泌尿器附近の手術瞋者の排尿障害率 $30.2 \%$ K 対し, 附近以外のもの $18.5 \%$ と云5差が出，手術部位 によつても，排尿障害に大きな影㨽のある事が云われま す, 最後に, 年令别ては, 幼年, 若年並に老年には比較 的障害率が少いと出て物ります, 以上の結果, この術後 排尿站害の間題には，複雑な種々の原因のある事が思わ れます，之に対し私達は先ず，障害原因の最も大きなも のとる考えられます。仰臥位より来る排尿時の精神的愃 害の克服のために，患者に対しねていての，排尿可能な 事，及び排尿現象の生理解剖学的な説明を充分にし又尿

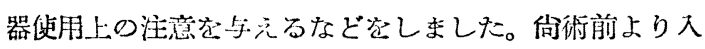
院している重者については，手術日が決つたなら，ねて いてと云う事に重点を物き，排尿練㫘をしてもらいまし た，実際には仰々難かしく，練既 1〜2 回目は尿器に慣 れないため，漏して布団を活したり，出ないのて4.50分 る尿器を市てたまま, 項張り大变な努力がいる㮞です。 スライドそは最近の排尿練㝗の結果です, この 11 人の 患者は, 術前 3〜4 日より練歪で全部ねていての排尿に 成功して括りましたが, 術後 3 人は温湿布之の他の処羅 にも出ないのて, 尊层しました, 此の3人は腰推麻酪て 然子, 内 2 人は子管剔出術䒚受计, 泌展器附近の手術之

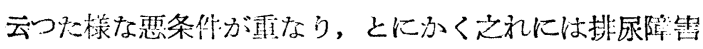
調査での，原因がま代問題上なつていると思います。他 の成功した焽者さんは, 術後の排尿が容易にH来, 練䏨 の結果を喜んで妨りました。

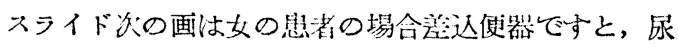
がはねやすく，有四を涯しやすい，年の心配と不安に対 し，私達は下の㥞な尿器を使い，此較的餧い成績を上げ ております。

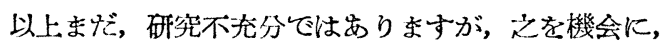
线された多くの間題を，引䋨き勉䦽してゆきたいと思つ て扣ります。

\section{3. 術中補液の問題体液の変動殊に 不成蒸泄に関連して}

長野 安䝮病院 小出来一博

「術中如何なる宣の液体を補充すべきかとい5 , 間 題を述べた。不成蒸泄量は，体重減少によりて現わされ るが，腹部手術では $2.8 \%$ ，肺結核手術ては $1.7 \%$ ，そ の他の手術ては $1.1 \%$ と割に多いるのでらた。不成蒸 浛量を間接的に知ることの出来る, ヘマトクリットは, 循環血液脱落量, 血嶈蛋白濃度とは並行閔係にあるが, 不成蒸泄の程度とは並行関俰にない。腹部手術に於て, 胸部手術より不成蒸泚量の多いことは, 細胞外液量の增 加率の大なることからも知ることが出来る。

更に不成蒸泄に影響を区ぼす因子に就て述へ, 術中に 於ては最少限度これだけの量は補充すべきてあり，これ を投与ない埸合に於ては, 術後乏尿, 無尿を起す危険の あることを指摘した。

\section{追加粉末ポリドールによる中毒症}

大分県 大分県農民潦荃所 城田 健夫

本年 5 月より 8 月屯て粉末ポリドールの粉末を連日微 量吸入した農協職员が, 頭痛, 頚血, 全身倦袁, 哂気を 訴元，白血球数 4,200, 血像に，エオジノ堌加 $12 \%$, 淋 巴球減少 $3 \%$ みた。

合好中球は殆んど全部が 4 分葉核を呈していた。また 民虜化膿し易いことも注意をひいた。

\section{追加農村に於ける術後栄养補給に就て}

長野 昭和病院 山田 栄吉

手術患者のの栄養提取を害らかに監督指導する事は, 重要なる治療の一分野である。殊に農村㭧者を报ら場合 一般に農家に於ける食生活は，多くは自給食品て睄われ る、所謂バッカリ食事に宿り，不均衡になる場合の多い 事を留意しなければならない。教類に依る满腹感に重点 が置かれ，動物性蛋白質も，提取総蛋白質の 1/4以下范 都市の $65 \%$ 前後で，牛乳，乳製品の使用も極めて少く この椂な食菋慣は病床に於てる脱し切れず，豊富なる栄

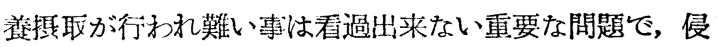
裂大なる手術患者ては特に之れを善導しなければならな い, 演者は虫垂炎, 胃潰瘍, 胃癌, 肺結核, 腎滅結核㭧 者の術後の栄養摄取情況を, 熱量, 栄養素に分けて分析 累計乙て術後患者の提食情況を概説して, その要を強調 した。

追加ポリドール中毒の経験例

長野 北信病院 梁 僙治

ポ削中毒の症状には, 固有の症状の外に, 猛毒に対す 
る恐怖感から来る，恐怖症に传ると思われるもの，区び 中請に対して㭧者の自己診断から，服用しているアトロ ピン錠に依るかと思われる症状等が考えられ，診断，鑑 別が必ずしも容易でない。農村の今後の一問題として協 力研究すべきものと思 5。

\section{追加気管内麻酔に際する筋弛縵剂の}

選択について

\section{長野 北信病院 平岩 邦彌}

吾々の外科で既に経験した6 例の気管内麻醉例から， その経過の一部て劣る，導入押管時に於ける筋驰緩郕を 種々使用し比較観察した。

在来迄に使用した「マイアネシン」「「クラーン」K ついて見ますと，前者では，効果発現時間が一定しな

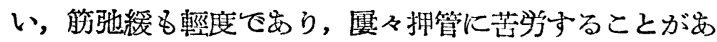
る。「クラーレ」使用時に際して効果の発現は一定して いるが 量的に美が著明て これを量的にコントロール するのは困難である 筇弛緩の程度は充分なるすのがあ るが そめ持続時間が長く 5〜15分侮然呼吸を見た。 最近新たに「サクシニール(s) ヒヨリン(c) クロライ ド(c)」を使用して搟管時に良結果を得た 即ち「S.c.c」 の効果発現時間は 30 秒て持続時間 1 分間 内外驰緩は 「クラーレ」と同様充分であつた。これを「 $2.5 \%$ 泫 ナール」0.3gk s, c, c20mg を混じて 30 秒で注射し 第正期 第五期に達して摴管を実施して その後の麻蠤 持続に悪影響を見ない考察「s, c, c」は「クラーレ」 に比して効果発現 消失が速ふで、無呼吸状態も前者に 比し $1 / 5$ 以下で市る，全身状態，特汇血压 脉膊 呼吸 の变化も前殾比し少し恢復が古い，以上市ら $\mathrm{s}, \mathrm{c}, \mathrm{c}$ ，在

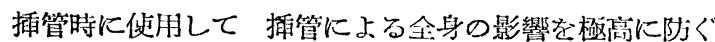
事が出来る。

\section{追加青森 三八城病院 泉山 涬吉}

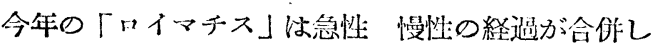

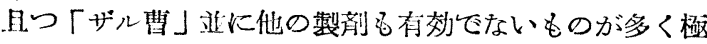
めて難治性のものが多い上5に思わ叔た 従つて吾々の 取扱つた患者の中には 類似の症例が品つたのかも知机 ないが 又「ロイマチス」の一型であるかも判からない

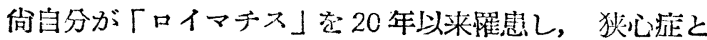
思われたの俩側大胸筋の「ロイマチス」でマッサージ

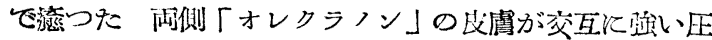

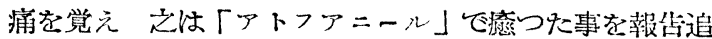
加する。

追加長野 佐久辆院 若月 俊一

Rheuma の本態については いろいろの論議がある
よ5ですが 私たちが この症例を Rheuma と区別し そ点は 云らまでもなく 㐫らゆる Solizyl-prpàarat の種々な治矮が 全然効果がなかつたとと。その他関節 の腫脹 その他の Rheuma に特有な臨床证状や既往症 が見られからたととです。

わちろん シンコルタも全然韭効でしたし ビタミン B Denergischな Kur あだめでした。

追加

長野 佐久病院 俊月 俊一

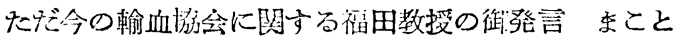
に有難らございました。厚く御礼申しあげをす。昨年本 学会のために「手術と栄䍿」について特別㜔演を御快 諾下され 特かげで 本年の総会には こんなにもた

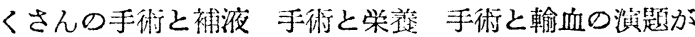
出まて熱心な討諭がたたかわされる結果になりました。 今後とも，よろしく本公のため御指導たまわらんととを 御願い致します。

\section{4. 同種(冷蔵)皮膚移植について(第II報)}

長野 伀久病院 排上 清美

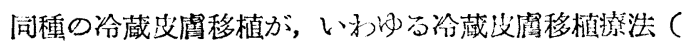
之には，自家移植を用5るのが，心つ5でするが）とし

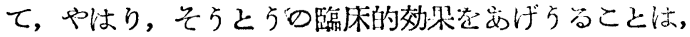
去年の本学会に特いて，私たちが第 1 報として報告した こころである。

その後, 症例をかさね, 33 例口経䏩を得犬ので, そ の組織撩法としての，臨床的効坚を報告すると其に，阔

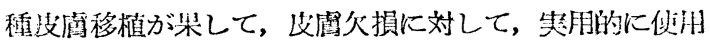
しらるものなりや否やの立場沐ら行つた，穴の病理組織

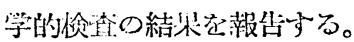

移植文福片は，大きさ $2.5 \mathrm{~cm} \times 3.5 \mathrm{~cm}$ 程度のもの゙ミ,

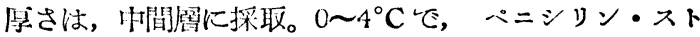

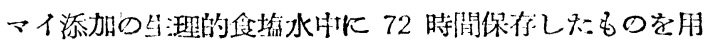
$\checkmark た 。$

組織撩法としての臨床的効果は, 关の後も战續よく,

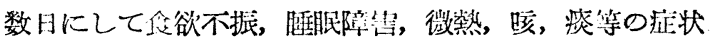
の輕快が大多数に执いてみられた。

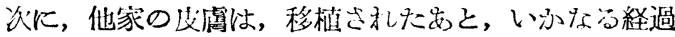
をとるかと云うと，早期に壊死になり，脱落したもの恃

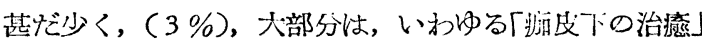
に似を経過をとるのであって，中には，一寸見て その ま东生着したと思われるよ5なもの（7\%) 自家移植の

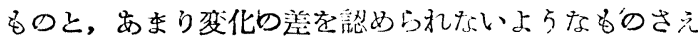
めつた。以上包事実はこの移植法が，实際的に創隹治

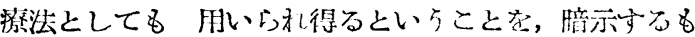


のではなかろらか。さいきん，Haut の Homotransploutation の問題は, 欧米でも，再ぴやかをしくなつ てきたよ5だが, 演者等も, この間題を, 更に追求して いきたいと考えている。

\section{5. 冷凍植曼術の経験}

長野 北信病院 永田ハジメ 袖田 弘道

われわれは, 暗和 24 年 11 月から, 昭和 27 年 12 月末 迄に, 神経痛, 口イマチス, 嗔息, 慢性胃炎等の患者 259 名の治潦に，チールシユ上法による「冷蔵植支術」 を行つたが，この治療効果と遠隔成績を調べて報告し 合せてとの治撩法に就て若干の考察を試みた。

\section{6. 蔵器 (組織) 埋沒療法に関する基磷的研究}

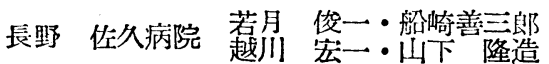

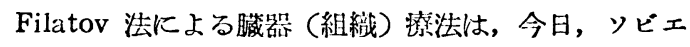
ットは勿論, ヨーロッパ 中国, 又, 日本に特いても, 広く行われるに至つている。しかし，Filatov の理諭一

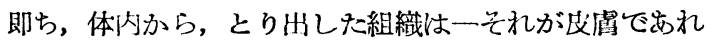
胎盤更あれ，0〜 $4^{\circ} \mathrm{C}$ に冷藏すると，いわゆる Biogenstimulator がその中にできて， そが再び生体内に埋没 移植されると，その生体の，一般的治滺力を增進せしめ る,といら理論は，未だ一つの仮説である。

したがつて，そゆ臨床的応用㤝，たくさん行われ，そ の勃果も，大いに悡められるに至つていても，その本熊

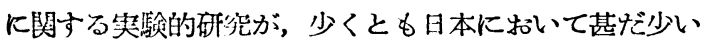
と云うことは，甚げ残念なととである。

私たちは，その意味から，次の上5な実験を行つて， その本態の一面を, 病理組織学的立場から, いささか究 明いたしたいと考えた。

Filatov 法によつて冷蔵処理した, 人間の胎盤, 又は 動物の筋肉片を，汶下組織内に埋没移植した場合この 移植片に対して，周围の生体組織が，どのよ5に反応す るか, 果して, Filatov 法による冷蔵処理した組織片に 特異的な区応過程を見出せるかどらか。

实験動物には，家农14匹，モルモット28匹をつかい 移植片には，人間胎盤のほかに，動物筋肉(自家区他家) 牛の脳下垂体を用いた。

これらの移植は，次の三方法に分けて皮下に行つた。

1）いわゆる Filatov 法に処理したものの移植。

2） $70 \%$ Alkohol に固定したものの移植。

3）生のものの移植
更に，Kontrol として Spongel片を，同様に 皮下 埋没を行つた。

埋没を行つた周囲の組織の標本は,すべて, 5 日目 10 日目，15日目に採取し，へマトキシリン・エオジン，、 ロリー，エラスチカ・ワンギーソンの染色を行い, 一部 は,アルデヒード・フクシン・マッッンの法を用いた。 以上の所見は，我々の検荣した組織標本の中では， Spongel が，一番輕い反応を惹き起し，胎盤移植片，そ の中でもことに，Filatov 法を施したものが，最も著 明な変化, 即ち, Fibroblasten の增殖, 血管新生等の 一種の增殖性の生体組織反応が，明瞭に見出されたと云 える。移植片としては, 人胎盤片が最も強度て,

次に筋肉片，次に脳下垂体の順に，弱くなるよ5な所 見を得た。さらK，同一組織片のちちで，Filatou 法 処理をしたものが, 最も強く、次化のものて Alkohol 処理のものは，最も弱い反応を示すようである。

以上の動物実験の結果が, Filatov 法を施した，胎盤 組織片の皮下埋没による移植法が，即ち組織潦法が治療 法としてすぐれたものであるといら值接的な根拠を示す ものではないにしても，少くとも，その一つの面を解明 少る事帮としてあげらるのではないかと思われる。

\section{7. 佐久病院輸血部に於ける供血 の諸問題について}

長野 佐久病院 牛山弘交・飯島 裕一

追加 順天堂医大教授 福田 保

最近の外科の手術には，著しいものがあります。手術 に関し患者の栄養問題は，技術と同様に重要であつて, 栄荃低下では手術の良結果は得られないととは，一般と 認められて来ました。只今も手術後の栄養間題の御講演 がありましたが、私は興味を以て拝聴いたしました，農 村に於ける栄養間題は特に大切なるのと思います。経口 的栄盖摄取を一時停止され易い手術に関し，輸血の必要 は当然起つて来るわけであります。輸血対策につき農村 に於ける御苦心の程をつぶさと择聴いたしました。供血 は血液の売買ではないので, 病気て忷んでいる手術患者 に悪を以つて血液走提供するのて，之の御礼として俸収 をいただくのだと言らことを，一般民采に教育すべきす のでしよ5。将来当然設请されね代なら好血液銀行に関 しては余程の設㣁がない以上，千葉県に於けるよらな事 件の起り得る心配があります。病気の負担は極めて大 なるものがありますので，その開設資金はどこからか 揄出することを考虑すべきでしよう。 
とに角輸血の間題は殊に困難を伴ら農村ては将来の大き な間題でしょう。

追加農村に於ける給血協会設置を提唱する 長野 昭和病院 山田 栄吉

一般に輸血機関の設置されて居ない地方 特に農村に 於ては, 給血者の撰把は思家側より血刑適合者を得る他 なく 斯かる実情は輸血実施に対する大きな湓路とも言 5 可く 病院給血部設置の重要性は玆儿在る。然し所謂 一ケの病院内に設けられた給血部の恩恵は, その病院で 治療を求める患者に限られ易く一般患者はその恩恵に 預り難い嫌いがある。治療に於ける輸血の重要性は今 更云万迄もなく 又輸血は綜合病院に於てのみ実施され るものてなく 従つて斯かる給血機関は一般医師にも開 放し 常に如何なる場合にも会員を派遣し広く一般患 者にすその恩恵に浴せしめる可きである。私は当地方に 於ける 給血困難の湓路を打開すべく今春( 2 月中旬) 赤穂町役埸保険課に給血協会を設立して,一般医師の要 請にも応ずる輸血機関を設けた。〔開設に当り佐久病院 給血部より貴重なる資料と御助言を得た事を媣謝する?。 当初, 私は都会と種々の点で趣きを買にする農村地抔に 給血協会設置を提唱して, 果して一般の理解と共鳴が得

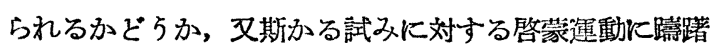
した。然し昨年 1 ケ年間の 外科に於ける輸血総回数は 778 回 給血者総数 683 名, 総輸血量は 15 万旔を逥る かに超過する情㫛て，少且つ，当院を中心に電車 1 時間 半以内の範囲に完備せる綜合病院は，7〜8 個所めるに す拘らず，開腹術丈けでも 3 ケ年に 1000 例を出て居る 現況は，輸血機関設置の重要性を如実に箵示するものと 考え，私は敢えて農村に於ける給血協会設置を試及提唱 した。幸い識者至幅の支持に依り，夢とも画いた農村の 給血協会は, 企図通りに設立され 輸血の困難は全く除 外され得て, 而も倘牤会員は遠地沿加れて, 給血奉 仕に任じて居る。農村と雖も給血機関は絶対に必要で市 る。輸血を必要とする重篤な疾病 外傷又は手術患者は 人の住む所常に存在し, 都会と農村を間わない。アメリ カては輸血夆仕事業を全国的運動として行い，1500ケに 及ぶ血液銀行と，多数の給血協会があり，輸血に不自由 しない現況は，羡望の限りと言ら可きである。農村に於 て給血協会を設立するには，一般に農民は，血液を提供 する事を嫌ら事を知らねばならない。従つて農村に於け る給血協会設立連動は, 先づ給血雍仕が病める者に対す る博愛的な愛の権化たる事を説く事に初まる可きと思 5

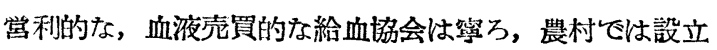

され得ないと思5。会員と患者の間に愛と感铸が行き交 ら給血協会とそ，給血協会の真の姿灾り，斯加る組織 は農村に於てとそ，産れ易きものと私は思5。私は農村 に於ける, 給血協会の設置は極めて重要であり, 而もそ の設置は農村と踓も容易であり, 躊踷するに当らない事 を特に㧛調する。

\section{8. 農村の骨関節結核}

静岡 遠州病院 加藤重三郎・内田時世 高示玄辰・片山鏡魴

1. 余等は前回に於て, 碩国なる腰痛が農村に於て多 発する事を報告した，今回は之等の腰痛の中て，結核性 症息が主因をなす症例に検討を加え，やはり農村に於て の, 之も高率である事が分つた。特に治療に困難を感ず る仙腸関節結核の数例に首剑移植を試み，其の绕秀なる 事を認め，合せて之が生体に及法す諸反応に就ても榆討 を加えた。

\section{9. 胃癌 94 例の手術成綪一附・その病理紬樴 学的検索}

長野 佐久病院 船崎善三蚛・越川宏一

過去 8 年間に手術した胃癌切除 94 例について, 切除摔 $65 \%$, 死亡率 $14 \%$, 治椥率 $20 \%$, の成績を得た。之 を内外諸家の瞃告と比較検討すると共に, 転移淋巴腺の 問題にふれ，切除胃についてこれの系統的検索を行い， そのいくつかの症例を示説し, 根治手術に対して, 淋巴 腺に対する態度は更に慎重を要すると結論した。

60. 私の実施せる胃切除手術 54 例について 杤木 下都賀病院 紅谷 篤男

私は最近 3 年間半に胃癌, 胃, 十二指腸潰瘍の 54 例 に対し，胃切除手術を実施した。手術はビルロート氏第 一法及び，第二法に僅かの变法を加味したものである。 54 例村 37 例は手術後 1 年以上経過を観察し，特第一 法を行つたものでは，時間を追つて胃夜及びX線像を追 求し得た。独に報告する次第である。

手術乃式 胃癌の場合は勿諭, 潰瘏の場合に於ても, 病樂を含々胃を可及的広範国に切除すべく, 又吻合後残 胃に，胃内容が筙滞しない事が必要である、私は小警側 では胃の殆ど全部を，大譬側では胃泡の部分のみを半月 状に残して広範に切除し，更に大繰側偶庙を一部再切除 し，吻合部としている。之で十二指腸と吻合する場合。 残胃を長経て 180 度右万に迴転し，十二指腸断端と端々 吻合する。空腸と吻合する場合は端側吻合とし，空腸輸 入脚を吊り上げ，第一次胃断端を覆被する。之所謂失 
調循環を妨いている。第一法の場合は吻合後の形態が恰 る小さな胃の如き形となり, 第二法の場合にも, 胃内容 の嚼帶はない。

次で手術後のX線像, 线胃の分泌状況, 最後に治療成 績を述べ口演を了う。

\section{1. 外科手術患者（虫垂炎，胃潰瘍，胃癌）} の診療実態について

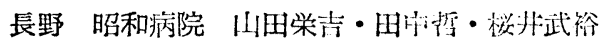

先般厚生省上りの指示に基き，医然施設面調查を当院 にて行つた際の一部である, 念性虫烡炎, 胃䟺瘍, 胃病 について, 大院期間中に施した, 手術, 処置, 検榃, 注 射, 投薬, 入院料等の治潦敗と, それらに要した費朋之 を検討し，報告する。

以上の各疾病患者の治療費に対する, 䒜際に姴した薬 品, 消耗材料の費用は概小2 $20 \%$ 前後であるが，虫匡炎 では2 $22.3 \%$ ，胃手術例ては虫垂炎炕比し，2３\% 低くなつている。

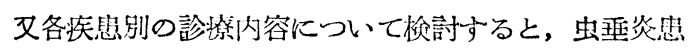
者の治療費に於て, 手術, 処置, 検査, 注射, 薬郕, 入 院等全治療費に対する割合は急性, 壊瘨性乃至蜂简織炎 性何れる大した相罯はなく，又夫くに要する費用の各治 療費に対する割合も同様大した差罚はない。腹膜炎，胃 潰瘍，胃癌となると，注射が相当大きな此を示し，薬郕 は実際に使用量も少くなり，注射の制合の增大に依り全 体に対する比は圧縮されている。

又各症患の手術のみについて見ると，手術に桉した䨘 用の手術科に対守る此は何れる10\%前後て，大した相 星を羿められない。

向手術に於ける, 篹品材料については, 各手術共, 術 前に使用する薬品も大した举罢はなく, 術中の薬品につ

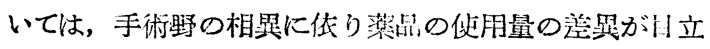
つ程度である。

又術前, 術中, 術後を通じ优用せる消耗材科では, 胃 切除術に於てガーゼ, 縫合絡が他のものに比し, 著しく 高い割合を示して，其の他の材料に就いては特别大きな 差翼を譛められない。

以上の調査は最近鬼牦論議の対照とされている，保険 診療に対する赫酬問題とも関連し, 意義あるものと思い 妶に報告する。
62. 最近 5 ケ年間, 当病院に於ける胃手術例統計 的観察並に農村, 都市比較

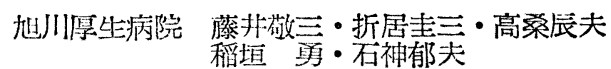

当病院過去 5 ケ年間の, 胃手術㭧者綂計上, 胃癌, 胃 潰瘍等患者が漸増の傾向を示して特り，且又，栍極的に 手術を受けるととを希望する者が増加して来た。即ち, 5 年間に亘つてみると，年間 30 名前後の者が漸増して 70 名を超えるに至つて来た。

叉各年令層についてみるに，若年者の胃患者も多発し ている。

脤村, 都市との対比に䇄て検討して若干の考察を加え た。

追加秋田 平鹿病院 立身 政一

最近 3 ケ年に 25 例の胃の全摘出例があるがその術式 に於て, 福田教授御発表飞㟧る, 食道, 空晹吻合術を行 ら様になつてから手術死亡例が全然なくなつた。こり席 より福田教授に感謝する。

追加青森 西北病院 松本 功

1. 御質問の十二指腸虫の寄生の件は，経験例はない

2. 腸間膜炎，並に腸内膜淋巴腺炎は 26 例飞於て特 に著明てをある。

3. アレルギーには䬭成しているのではい。

63. 腸蜂窩織炎の一考察

青森 西北病院 松本 功

西北病院では，過去 3 年間に 41 例の腸蜂窝織炎を経 臨するが，之等症例を臨床症状より Crohn の分類に従 い分けると，大多数急性腹内炎型て，病変部位は迴腸及 び廻腸末端に多い。腸蜂億織炎は，他腹部疾患を合仆す る埸合少なからず，就中，蜔蛼を伴 5 もが少なくな い, 余は 41 例中 28 例仁開腹時蜔虫の寄生を認め, 蜔虫 症と密接な関係㐫るを経䣅した。特に 4 症例に於て, 病 变部に一致し，末成熟蜔虫の腸壁架通するを確認し，腸 蜂简織炎の成因市中，かかる細小な寄生虫の直接腸壁 宗孔に上り惹起される, 細菌感染性炎衡もある点は特記 すべきものと考える。以上 41 例の統計的観察と共に, 腸蜂简織炎の成因に関し考察を加えた。

64. オスグート・シュラツテル氏病の穿孔療法

長野 北信病院 永田ハジメ・平岩邦啢

われわれは，昭和 20 年 6 月から昭和 28 年 3 月迄に， 28 例のオスグート・シュラッテル 氏病患者を治䝤した が，その内，飯野氏に上る第孔潦法を行つたものと，他 
の治療法を行つたものの治療成績と趗隔成績を歰べて比 较検討した。

\section{5. 急性胃捇張疾と誤られた移動囬腸症}

\section{による腸閉塞の 1 例}

杤木 佐野厚生病院 宇治 康明

上腹部膨满, 疼痛を以て突然発病し，急性胃㹡張の診 断の下に，各喠処置を施したが輕快せず，遂に腸管底痻 の症状を呈した思者。28才の女子、開腹術を行つた所 上腹部に著しく膨隆した盲腸，及び上行結腸あり，真腸 炎端部は左肋弓下に位置する。このため定迴腸は，压迫 されて左右に2分され，又上行結腸の，肛側の部で，腸管 の捻転女り，共に通過障害を起している。腸管の壊死は ない。全身状態不良のため整復 腸固定，廻腸横行結腸 物合を行つて，腹腫を閉鎖す。術後4日再び腹部膨满， 晹麻瘦ゆ症状出り開腹。結腸の一部壊死を認め 廻育 部切除術を行つた。術後の経過は一時良好に思われたが 衰弱加わり，7日後鬼籍に入つた。

以上の症例知床上急性胃脑張と診断したため，適当 な処置を取るべき時機を失い，不良な結果を取つたるの と思われる。

この様な症例，及び移動店腸症につき交献的考察をこ ころみる。

\section{6. 最近経験せる $\mathrm{S}$ 状結腸過腸症}

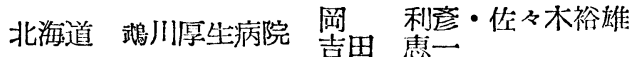

最近 1 年間，手術により治瘾せしめ得た本症 4 例につ いて報告し，作せてその発生機転について考察する。何 れも農業, 漁業に従事し, 過学, 急激な体位変換等に明 暮れる肉体学働者である。乘冀状の便，更に便秘と下淑 が交互し，ガスの排出により輕快する腹痛等本症に特有 な症状を主診とした。手術は S 状結腸切除術を施行した 中 2 例は移動性宣腸及び慢性虫垂炎を合例している。発 生機転については, 先天性素因出るものに突然症状を荡 起せしめた誘因として，過労，急激な体位变換，排便制 約等により腸各部の共同作用の障碍を特こして, 腸内容 の前進阻止を来たした結果，本症特有な症状を物こした であ万弓。更に移動性盲腸，及び虫垂炎の计発は，交感 神経を刺战して，腸運動を緩慢にし，便秘を抢こさせ，

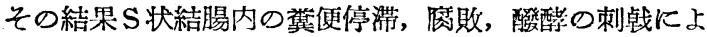

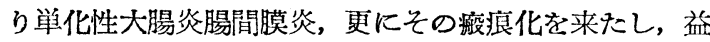
々症状要化に拍車を加える結果になつたと推量する。

67. 〔イレウス〕に依る小腸 4.3 米切除治験 1 例 茨城 取手協问病院 氏家 基・浜条 慶裕 近時外科学は大なる発展をなし，往時に比して手術侵
㦼の範囲は著しく增大されたが，然し腸管切除の限界に 関しては，確固たる見解が必しる確立しているわけでは ない。我々は急激且つ広汎性に，小腸の壊死を来せる 59才の〔イレウス】患者にやむを得す圆険にも小腸切除43 米を行い, 率いにる救命出来, 現在份生存を続けている 例を経験した。之は主として術中，術後の大量の靽血の 実施が[ショック]防上に与つて力あり。救命し得た最 大の原因であると考えている。更に斯る全小腸の約 3 分 の 2 程度に相当する腸切除は，人体に及ぼす喝響は極め

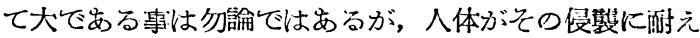
得る可態性がある事を，如実に此処に実証し得たるのと して海に興味泻いるのがある。

\section{8. 檤隔洞皮核震睡の 1 例}

杤木 㙁谷病院 比企員馬 小山倳治

症例 31 才の家婦，胸骨後部膿瘍の臨朋診断の下に， 開胸手術を行い，その結果，維隔に発生せる皮様覀腫と

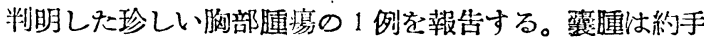

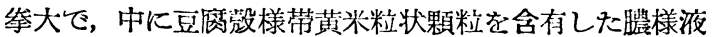

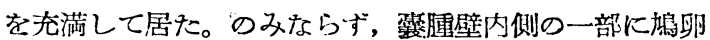

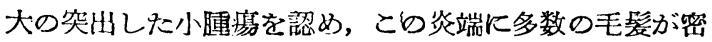
生していた。症状発現以来 2 年 10 ケ月，只間最初の 2 ケ月程の間，時に胸痛呼吸困嗼等が方つたが，他は全 く無症状渭過し，本年5月，腰痛を主訴として我々の 外来を訪れ，6月16日手術，6月30日退院経過茥だ良 好で，一予後も恐らく良好なものと思われる。

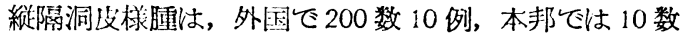
例報台せられて居る。本邦での終戦朔の報告は，全く之 を見ない程である。近来の胸部外科の発達に伴い，今後

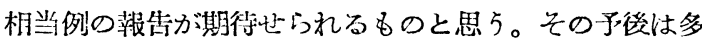
くは不良であつて，本思者平均㱜亡年令は 32 才と云う。 摘出物の病理組織学的梌索についてもこれを傡せて報 台したい。

69.「栗イガ」刺賃部に生じた肉腫の一例

茨城 友部協同病院 角田 種上

60 才女，1年前石足裔に「棸イガ」を刺しそこが魚 の日」椂になり，遂に肉脡となつた例に就いて報告した い。

70. 横手地方に於ける肺結核患者 の統計的钼察(第 1 㪕)

秋田 平鹿病院 树上喜秋・頜川栄城健郎 高波 朗・平不宜子

我々は秋田県横手地うに於ける肺結核鳃者の実態を医 
学的立場より行 5 目的を以て調査を進めているものであ りますが，今回は，その第 1 報として昭和 28 年 1 月よ り同年 8 月現在迄口大院患者 223 名を対象として行い， 将来第 2 報として，外来㭧者の同様調查，反び殊に㖘村 の家族内感染，及び発病の調査を行い，発表の予定であ ります, 今回の調査项目と致しまては, 家族歷既往症, ッベルクリン区応の有無, 感染源と思われるものの有無 健診の有㫮，肺結核発見力法 (集検心訪医か)，受診の 動機, 発病の誘因上思われるものの有無, 受診前就業状 態 (重中輕) 初診時 (大院時), X線所見, 赤血, 及び 塗沫椧査上結核菌の有無等の如きものであり, 此等の項 目に就き総括的に御報告申し上げてみたいと思います。

\section{1. 岐皁県某村結核実体調查報告}

畦帛 山県病院 佐藤 源

農村に於ける, 結核の董延の形については, 既に多数 の調査成結が報告されて，ここに新らしく述べるまでも ない。

日常農村の医療に彷事するものにとつては, 各部落の 結核発生の特虽性の把层に努め, 其の䂆防面にまで進辰 してゆかなければならない。

私道は最近 2 年间に, 公式の記録には結核多発のデー ダーは出ていないが，日常の浐療に結槅蔓延の推定が考 へられる岐皁県某村人口 2000 余名について, 保健所, 開業医と協力して, 結核検診を行つた。村民の主なる職 業恃農業，紙製造を主体とする山間の部落てある。其の 成續について報告する。

\section{2. 费村結榣に於けス結核菌而性試験之臨床成綪}

山口阔東病院 影山是治・坂本太郎・井倉脱

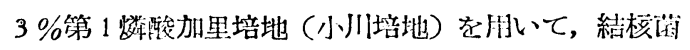
のSM, 及びI N A H 而性学直接测定したが, この培地 は操作が簡単で時間もかからず, 我々臨床家にとつて㥑 秀な培地と思 5。

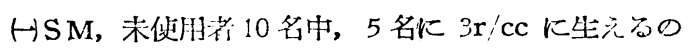
を見たが褧的には少い，而も是等の輕度耐性所持者の大 部分は比較的新しく発病したと，推定されるものである

$\Leftrightarrow$ 一般にS M - I N A H共に, その使用量の增加に従 つて, 耐性の度が高くなつている。

印空洞の程度と, 耐性の関係では, 空洞の大い程, 又 数の多い活ど，耐性を生じ易い，空洞の認められないる のに於ては，晸めて大量を使用しなければ嗝耐性を示す ことはない様である。

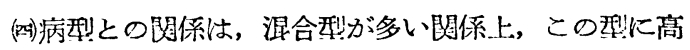
酎性を示するのが最も多い。又重症なもの活ど高耐性を
示寸。

量)喀出痰量との関係では, 量の多いほど高而性を示す 率が多い。

(出 S M・I N A H共に，耐性出現心高いほど効果を認 めなかつた。特に SMでは, 100r 以上のもの, I NAH に於ては10r 以上のものに於て著明で㐫る。 SMでは, 臨床的耐性と云われている 10r/cc のものでる，量的に 少いもので著効を認め得た。

(t)対照集落の 10 数個位しか生えていない少数集落よ りの，耐性試験に於て 1000rを示したるのに使用し著 効のあつた例があつた。それで, 少数集落の場合は,な を慎重に検討与る必要があるよ5に考える。

\section{3. 農村に於ける肺結核治療に関する観察}

岐皁 高田診療所 宇佐美 弘・岩田行子

本診療所の外来患者, 区び巡回䛦療受診者中の肺結核 患者について，若干の考察穵行つた。

1. 農村に执いて子肺結核は，その学働力低下に重大な 影響を与えていると推察されるにる拘わらず, 早期発 見の機会に急まれていない。

2. 既往の治療を検討してみると，「安静」及び「感染 防止」に関して，医師側上り充分な指導が行われず, 為に患者のららにはこれ等に関して，無智に等しいる ののあることをしつた。且、その治療は, 化学治療が 抏しく偏重され，基本なるべき大気安静の輕視，虚脱 療法に対する無智等が相侯つて, 適切てないと判断さ れるものが少くない。

3. 明らかな誤診に基く「結核のない肺結核患者」が银 きは数年にわたつて，治療をうけていたとゆら数例を 経験した。

\section{4. 結核化学療法に依る農村肺結核患渚の治験}

\section{不川 加賀東病院 山下賢太郎}

重症肺結核 7 例, 中等症 15 例, 輕症 8 例計 30 例飞つ き，大体結核予防法の基隻に従い，S，M（1日1瓦凡之 40瓦), PAS (1日 6 8 酉計 400 瓦) 仵用療法後2週間

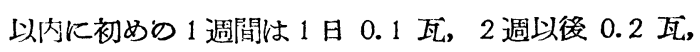
食後 3 回に分服, 各菜剂終了後の効果, 並に綜合的臨床 効果を検した。

体温: 平熱となりたる者 18 例 $(59,4 \%)$, 即ち作用療 法に依り 7 例 (23.1\%) が平熱化し，少微熱を有する 者的, INAH 服用《依り 2 週目頃上り漸次下降し初め, 終了迄に 10 例 (33\%) が平熱化した。向 1 例に於ては, 何れの薬滖に対しても不变であり, 却つて増恶せる感を 与えた。 
体重: 食思の增加に伴、体重る增し, 虫卵を有せる者 は那虫後, 速かに回復し, 全体として $2 \mathrm{~kg}$ 以上増加世 万者 10 例 (33\%)，4kg 以上. 13 例 ( $42.9 \%$ ) 計 23 例 (75.9\%) に於て増加を見た。

血沈: 平均値を平均 $10 \mathrm{~mm}$ 以下とし。又 $10 \mathrm{~mm}$ 以上. の変動を以て遅速の規準としたが，平常化せる者 11 ,

(36.3\%)，遅延 16例 (52.8\%) であつた。

喀瓷中結核菌：治療開始前, 作用療法終了後, INAH 服用後，それぞれ各 2 回連続培盖を行い，平均集落数を 算へ, Gaffky の如く号数を定め, 菌の消長を見るに, 培養陽性者 24 例 $(78.2 \%)$, 全経過中不变の者 8 例(33. $3 \%)$, 減少せる者 12 例 (50\%), 消失世る者 4 例 $(16,7$ ), むり。

INAH 服用後の 12 例飞つ小て, INAH 抵抗試験を行 つた結果，2例に 10r，4例に $1 \gamma$ ，の抵抗出現あり，他 の6例には抵抗性を認め得なかつた。

乙線所見: 重症 7 例に於ては 1 例増悪他は不变, 中等 症 15 例中 11 例に改善を見, 輕症に於ては 8 例中 7 例に レ線所見の改善を見た。

Thioacetazone に関しては現在実施中K付き省略し 次の機会に報告する。

\section{7. 結核性䐬胸の非観血的療法に就て}

$$
\text { 静网 遠州病院 苮石敏夫 ・鈴杰博 }
$$

吾々が行つている結核性膿胸の非観血的䝤法の術式は 透視を行いつつ套管針を患侧肋膜腔内一到達せしめ, 内 径約 1 粍のビニール管を㨂入，套管針を除去しビニー 几管を小金属板にて, 胸壁に固定, 該ビニール管を通じ て, 肋膜腔内への薬液の注入区び，洗滥を行 らのであ る。

薬液としては, ヒドラジット溶液及び, PAS 溶液拡散

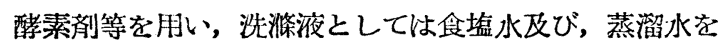
用いた。本法の特徴としては, 摟孔形成の皆無なる事, 患者に疼痛を感ぜしめない事及び，管を通じ，外界と接 触する事に依り, 肋膜腔内の肉芽組織形成を盛んならし める事を举げる事が出来る。吾々の経験せる所では, 治 療効果には大いK見るべきものがあつた。

\section{X線上著変を認めない結核性気管支潰蕩}

の 1 例 (長期喀血, 血疼の治験例) 新潟 小国病院 成沢 四郎

気管交結核については, 近時儤々論述され, 取訳, 結 核の治療上，特に虚脱㙩施行時，その有無か阔題とな り, 頻繁に実施されつつぬる。
一カ文，X線上著变を認めないが，微量批菌源となる 気管支結核も考虑され，三，三報告されている。私の1 例は, 数カ月に亘る継続せる喀血, 血乲の為に所々を転 々とし，その原因不明の虂に止血剤を投与されていた。 気管交鏡検査に上り気管，気管支分岐部，及び左上葉気 管交開口部近く粗裂な，一部荅の附着した深い出血倾向 ある結核性潰瘳を認め, 直にパス $1200 \mathrm{gr}$ ，ストマイ35gr を施行したが，治憭中 1 回䛓嗽時小血痰を見たが，日な らずして止血し，治療中止後 8 カ月間経過を観察してい るが, その後 1 问の客血, 血答も認められない, 因に本

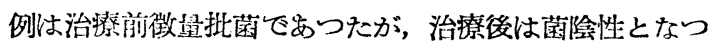

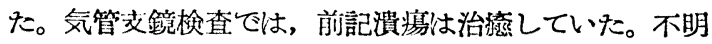
の喀血, 血乲の原因を気管爷結核に求め, 此が㚮置によ り全治せめた 1 例を経験した。

\section{7. 小児胆石症症例}

秋田 雄勝中央病院 大谷博信・丹野邦照月正

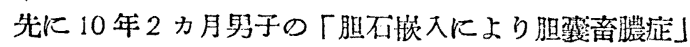
を東北外科集談会に於て発表したが，偶々再び 10 年 2 カ月男子の「急性胆霊炎区び総輸胆管内胆石」を手術し たのて，其概要を発表した。而して前者の胆不を，弘前 医大傎教授に依頼したるに，其中榜をなすは蜔虫甽なる ことが証明された，後者の胆不も特々らく，蜔虫卵，或 は蜔虫クテクラを中核とするものであろう。

前者の胆不は $1.5 \times 1.5 \mathrm{~cm}$ 大のるのであり, 後者の 胆不は $2.5 \times 1.5 \mathrm{~cm}$ 大もので学る。大きさからは初発

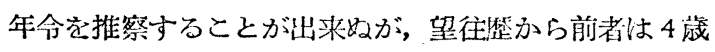
頃，後者は6荿场に発生したものと推定される。

今迄は成人の病気とされていた䏣不症が，小韭にも存 乙, 份且つ, 蜔虫と間倸あることが明膫になつたので, 農村の搌虫対策に新らしい間題を提供したことになる。

\section{8. パンピングに依る一側性外旋神経麻痺治験例}

\section{䈏山 礛波厚生病院 千羽 淳}

73 才農夫の飲酒後に見られた一側性の外旋神経麻㾴

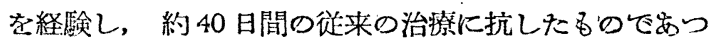
たが，VI3 便用に依るパンピングで術後 2 日日よら，外 転運動が輕快し始め, 1 カ月にて完治した 1 例を報告し た。

原因火就いては，酒瑇以外に考只られず，办冬の障碍 部位は，一側の外旋神経核を撰択的に犯したものか, 或 は，その末梢神経を犯したるのか不明である。 


\section{9. 喘村社会階級と衛生}

枋术 絹島村国保讋憭所 国見 辰雄

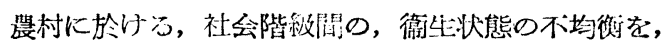
栃訃県絹島村を対象として, 調查したものの内ふら, 若 干選んで報告する。

日本の農村に於ける社会医学の研究には, 農業の比重 が罢なる㖘村の社会階級を分析しなければならない。私 は, 社会科学的琺に依つて, 之を, 地主, 富㩔, 富裕

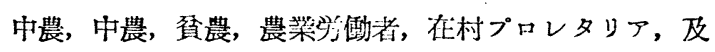
びその他の階級の 8つに区分し, 更に経济状態を全村,

A，B，Cの3つの階尿に区分した,

第 1 K，結核の，昭和 20 年氺ら 8 年間に於て，結核 死数及び，結核㭧者数を階級別に調査した所，明以かに

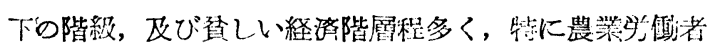

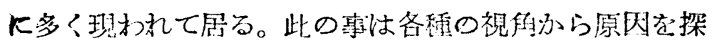
索しなけ机ばならないが, 只の1つに，感染系紶の調查
を挙げると，全 75 名の結核㭧者の $41 \%$ は村外感染でせ り，而も气の大部分は出稼感染厄方。その出稼感染を 受けるものは, 農業では生活維持うるに时難な階級, 即 ち, 頚農と, 農業労働者である。

第 2 K, 8 年間の急性伝染病, 特に赤痢, 疫病, 日本 脳炎の階級別発現度を調べた所，明らかに下の階級及び 階層程数倍の䍜患率を示し, 特に, 日本脳炎は, 全例, 最も頚しい階層に集中して現われて居る。

第3K，乳呪の衞生状況について見ると，出生時下の 体重は，階級，階層間に共に有意の差を認めず，各月令 別の発育は, 体重を以つて表わすと, 上の階級, 階層程 良好となつ居る。而るに, 满 1 才末满孚览の死亡率は, 8 年間の観察では, 上の階級, 階尿程高い。此の㝷は, 半卦建的農業の特貿として, 農業の比重の高い階級程, 母親の然働が強化されて居る慗を示して居る。 